\title{
Photolytic and photocatalytic transformation of methadone in aqueous solutions under solar irradiation: kinetics, characterization of major intermediate products and toxicity evaluation.
}

Cristina Postigo ${ }^{1}$, Carla Sirtori ${ }^{2}$, Isabel Oller ${ }^{2}$, Sixto Malato ${ }^{2}$, Manuel Ignacio Maldonado ${ }^{2}$, Miren López de Alda ${ }^{1}$, Damià Barceló ${ }^{1,3,4}$.

${ }^{1}$ Institute of Environmental Assessment and Water Research, (IDAEA-CSIC), Department of Environmental Chemistry, C/ Jordi Girona, 18-26, 08034 Barcelona, Spain.

${ }^{2}$ Plataforma Solar de Almería (PSA-CIEMAT), Carretera Senés, km 4, 04200 Tabernas Almería, Spain

${ }^{3}$ Catalan Institute for Water Research (ICRA), Parc Científic i Tecnològic de la Universitat de Girona, Edifici H2O, 17003 Girona, Spain.

${ }^{4}$ King Saud University, Box 2454, Riyadh, 11451 Kingdom of Saudi Arabia.

${ }^{*}$ Corresponding author:

Cristina Postigo Rebollo

Institute of Environmental Assessment and Water Research (IDAEA-CSIC), Department of Environmental Chemistry.

C/ Jordi Girona, 18-26, 08034 Barcelona, Spain

Telephone: +34-93-400-61-00, Fax: +34-93-204-59-04

E-mail: cprqam@cid.csic.es 


\section{ABSTRACT}

The present manuscript describes the transformation and mineralization of methadone (MET) in aqueous solutions (demineralized water (DW) and synthetic municipal wastewater effluent (SWeff)) by natural solar irradiation and two solar photocatalytic processes: heterogeneous photocatalysis with titanium dioxide $\left(\mathrm{TiO}_{2}\right)$ and homogeneous photocatalysis by photo-Fenton. Direct solar irradiation resulted in almost complete transformation of MET in the investigated matrices after 20 hours of normalized irradiation time. MET photocatalytic transformation required shorter illumination times in DW compared to SWeff. Only 16 and 36 minutes of solar illumination were required during photo-Fenton and photocatalysis with $\mathrm{TiO}_{2}$, respectively, to transform MET completely in SWeff. Mineralization of the dissolved organic carbon took place only during photocatalytic treatments. Kinetics parameters were calculated for processes comparison. Additionally, phototransformation intermediates generated during each treatment were investigated and characterized by means of ultra-performance liquid chromatography coupled to quadrupole-time of flight tandem mass spectrometry (UPLCQqTOF-MS/MS). The main MET phototransformation pathways were observed to be hydroxylation, and fragmentation and cyclisation. According to the Vibrio fischeri bioassay, the acute toxicity of the generated phototransformation products was not relevant, since the observed inhibition percentages of bacterial bioluminescence were always below $30 \%$ after 30 minutes of sample contact.

Keywords: methadone, solar photo-Fenton, solar $\mathrm{TiO}_{2}$ photocatalysis, solar photolysis, phototransformation products, liquid chromatography-tandem mass spectrometry 


\section{INTRODUCTION}

Methadone (MET) is a synthetic opioid mainly used to treat opioids addiction. Like many other illicit and licit drugs, this substance has been usually found in environmental waters, due to its low elimination efficiency in wastewater treatment plants that base the secondary treatment on activated sludge processes. MET efficiency removals have been reported to be usually below 40\% (Boleda et al., 2009; Terzic et al., 2010). Even higher levels of MET have been occasionally found in effluent wastewaters compared to influent wastewaters (Boleda et al., 2007). The presence of this compound in treated wastewaters and in river surface waters reaches levels up to $735 \mathrm{ng} / \mathrm{L}$ and $18 \mathrm{ng} / \mathrm{L}$, respectively (Boleda et al., 2009). MET residues have been also detected in surface waters from lakes at maximum levels of $2.5 \mathrm{ng} / \mathrm{L}$ (Berset et al., 2010; Castiglioni and Zuccato, 2010) and in groundwaters at levels below $0.5 \mathrm{ng} / \mathrm{L}$. Moreover, MET residues have been quantified below $3 \mathrm{ng} / \mathrm{L}$ in treated drinking water (Boleda et al., 2009).

These concentrations, although very low, may pose an environmental risk to aquatic organisms, not yet investigated. Reducing aquatic environmental levels of MET requires the use of more efficient water treatment technologies. In this respect, advanced oxidation processes (AOPs) are being considered as an alternative to conventional water treatments. AOPs, which are characterized by the production of oxidative species, mainly hydroxyl radicals $\left(\mathrm{HO}^{\circ}\right)$, have been observed to successfully remove and even mineralize organic microcontaminants, such as pharmaceuticals and pesticides, present in aqueous solutions (Klavarioti et al., 2009). However, they are not fully implemented since they would increase water treatment costs, which can be reduced by using catalytic AOPs (as $\mathrm{TiO}_{2}$ and photo-Fenton) and sunlight as source of irradiation (Malato et al., 2009). Compound oxidation by means of $\mathrm{HO}^{\circ}$, which also occurs in the environment, may involve several reactions that take place in a non selective way: eletrophilic addition at unsaturated $\mathrm{C}-\mathrm{C}$ bonds or in aromatic rings $\left(\mathrm{HO}^{\bullet}+\mathrm{R} \rightarrow \mathrm{HOR}^{\bullet}\right)$, electron transfer $\left(\mathrm{HO}^{\bullet}+\mathrm{R} \rightarrow \mathrm{R}^{+\bullet}+\mathrm{HO}^{-}\right)$, and hydrogen abstraction at $\mathrm{C}-\mathrm{H}, \mathrm{N}-\mathrm{H}$ and $\mathrm{O}-\mathrm{H}$ bonds $\left(\mathrm{HO}^{\bullet}+\mathrm{RH} \rightarrow \mathrm{R}^{\bullet}\right.$ 
$+\mathrm{H}_{2} \mathrm{O}$ ). Additionally, organic radicals generated may react with atmospheric oxygen to form peroxy radicals that generate further oxidative transformations $\left(\mathrm{R}^{\bullet}+\mathrm{O}_{2} \rightarrow \mathrm{RO}_{2}{ }^{\bullet} \rightarrow \mathrm{CO}_{2}+\right.$ products) that contribute to the complete mineralization of the organic matter (Legrini et al., 1993; Malato et al., 2009).

In the present work, the performance of two photocatalytic processes in the transformation and mineralization of MET aqueous solutions was investigated. These treatments, namely heterogeneous photocatalysis with $\mathrm{TiO}_{2}$ and homogeneous photocatalysis by photo-Fenton, were assisted by solar irradiation, and their application has been described in detail elsewhere (Malato et al., 2009). Photocatalytic experiments were run at pilot plant scale by means of compound parabolic collectors (CPCs). The chemical solar transformation of MET was compared to its natural solar transformation. All experiments were performed on two aqueous matrices (demineralized water (DW) and simulated effluent wastewater (SWeff)) to evaluate the effect of the water matrix on the transformation process. In this context, the main objectives of this study were to evaluate the transformation kinetics of MET under the investigated treatments in DW and SWeff, to identify and characterize the main phototransformation products originated in each process, and to evaluate the acute toxicity of the photoproducts generated.

The study was performed at higher than environmental concentrations in order to facilitate the study of the kinetics reactions and the identification of the photoproducts generated. This aspect may slightly affect the photo-transformation kinetics but not the transformation pathways observed, since they are governed by the active oxidant species involved, and not by the contaminant concentration.

To the authors' knowledge this is the first study in investigating the photocatalytic transformation of MET in water. 


\section{EXPERIMENTAL}

\subsection{Chemicals and reagents}

Methadone hydrochloride salt (purity, $>99 \%$ ) was provided as a concession for research purposes (2009C00124) by the Division of Narcotic Drugs and Psychotropic Substances of the Spanish Agency of Pharmaceuticals and Medical Products. High purity (>99\%) standard solution of 2-ethylidene-1,5-dimethyl-3,3-diphenylpyrrolidine (EDDP) (perchlorate salt) was purchased from Cerilliant (Round Rock, TX, U.S.A).

DW used in the experiments was obtained from the Plataforma Solar de Almería (PSA) demineralization plant (conductivity $<10 \mu \mathrm{S} / \mathrm{cm}, \mathrm{Cl}^{-}=0.7-0.8 \mathrm{mg} / \mathrm{L}, \mathrm{NO}_{3}{ }^{-}<0.2 \mathrm{mg} / \mathrm{L}$, organic carbon $<0.5 \mathrm{mg} / \mathrm{L})$. Demineralized water was also used to generate SWeff. The chemical composition of the SWeff is detailed in Table S1 (supplementary material), and was derived from the guidelines established by the U. S. Environmental Protection Agency (USEPA, 2002) and the OECD for moderately-hard synthetic freshwater and synthetic sewage (OECD, 2001).

Heterogeneous photocatalysis was performed using $\mathrm{TiO}_{2}$ Degussa P-25 (Frankfurt, Germany). Reagents used in the photo-Fenton experiments were iron sulfate heptahydrate $\left(\mathrm{FeSO}_{4} \cdot 7 \mathrm{H}_{2} \mathrm{O}\right)$ and hydrogen peroxide $\left(\mathrm{H}_{2} \mathrm{O}_{2}\right)(30 \% \mathrm{w} / \mathrm{v})$, and those used for $\mathrm{pH}$ adjustment were sulfuric acid $\left(\mathrm{H}_{2} \mathrm{SO}_{4}\right)$ and sodium hydroxide $(\mathrm{NaOH})$. All of them were purchased from Panreac (Barcelona, Spain).

High performance liquid chromatography (HPLC)-grade acetonitrile (Merck, Darmstadt, Germany) and water produced by a Mili-Q ultra-pure water system from Millipore (Milford, MA, USA) were used for HPLC analyses. Ultra-performance liquid chromatography (UPLC)-grade acetonitrile and water (Merck) were used in the analyses with UPLC coupled to quadrupole-time of flight tandem mass spectrometry (UPLC-QqTOF-MS/MS). Formic acid (purity, 98\%) added to the chromatographic mobile phase was acquired from Fluka (Buchs, Switzerland). 


\subsection{Hydrolysis, photolysis and solar photocatalysis experiments}

All hydrolysis and phototransformation experiments were carried out during summer at the PSA (latitude $37^{\circ} \mathrm{N}$, longitude $2.4^{\circ} \mathrm{W}$ ).

Concerning hydrolysis and photolysis experiments, individual solutions of MET were prepared by dissolving the compound in DW and SWeff at an initial concentration of $10 \mathrm{mg} / \mathrm{L}$ in $5 \mathrm{~L}$ Pyrex beakers. This value is much higher than reported environmental concentrations (Boleda et al., 2009; Fatta-Kassinos et al., 2011); however, it was chosen as MET initial concentration $\left(\mathrm{MET}_{0}\right)$ for better evaluation of transformation kinetics and photointermediates generated. The beakers containing the MET solutions were kept in the dark at room temperature during hydrolysis experiments and they were exposed to direct sunlight for 6 days during the photolysis experiments. Samples were taken periodically after water solutions stirring.

A CPC reactor was used for the photochemical assays. The photo-reactor is composed of two modules of eight Pyrex glass tubes mounted on a fixed platform tilted $37^{\circ}$ (local latitude), providing a total irradiated area of $3 \mathrm{~m}^{2}$. The total volume in each experiment was $35 \mathrm{~L}$, but only $22 \mathrm{~L}$ were irradiated. At the beginning of all photochemical experiments, homogenization of the $\mathrm{MET}_{0}$ concentration and the reagents added to the process was done with the photoreactor covered to avoid any photoreaction during preparation.

In the $\mathrm{TiO}_{2}$ heterogeneous photocatalytic experiments, after addition of the drug to the photoreactor, the system was well homogenized for $15 \mathrm{~min}$. Subsequent addition of the catalyst $\left(\mathrm{TiO}_{2}, 200 \mathrm{mg} / \mathrm{L}\right)$ required also homogenization of the system for $15 \mathrm{~min}$ more. A homogenized sample was collected before uncovering the photoreactor and starting the photocatalytic experiment to check $\mathrm{MET}_{0}$ concentration. 
In the photo-Fenton experiments, after homogenization of $\mathrm{MET}_{0}$ concentration in the photoreactor, the $\mathrm{pH}$ of the water was adjusted with sulfuric acid $\left(\mathrm{H}_{2} \mathrm{SO}_{4}, 2 \mathrm{~N}\right)$ in order to carry out the photo-Fenton reaction at a fixed $\mathrm{pH}$, between 2.6 and 2.8. After 15 min of homogenization a sample was taken to confirm the $\mathrm{pH}$, and afterwards, the iron salt $(2 \mathrm{mg} / \mathrm{L})$ was also added and well homogenized for 15 min more. A homogenized sample was collected also before adding the first dose of $\mathrm{H}_{2} \mathrm{O}_{2}$, which was kept always in excess (5-20 mg/L) during the experiment, and prior to uncover the photoreactor.

All the photochemical experiments were performed at different days between 9 am and 4 pm. Solar ultraviolet (UV) radiation was measured by a global UV radiometer (KIPP \& ZONEN, model CUV3) mounted on a platform tilted $37^{\circ}$ (the same as the CPC reactor). Comparison of the data obtained with diverse photochemical experiments carried out on different days is possible using equation (1) as described elsewhere (Malato et al., 2003); where $t_{n}$ is the experimental time for each sample, $\mathrm{V}_{\mathrm{i}}$ is the illuminated volume, $\mathrm{V}_{\mathrm{T}}$ is the total volume, $\mathrm{UV}$ is the average solar UV radiation measured during $\Delta \mathrm{t}_{\mathrm{n}}$, and $\mathrm{t}_{30 \mathrm{w}}$ is the normalized illumination time that refers to a constant solar UV power of $30 \mathrm{~W} / \mathrm{m}^{2}$ (the typical solar UV power on a perfectly sunny day around noon).

$$
t_{30 w, n}=t_{30 w, n-1}+\Delta t_{n} \frac{U V}{30} \frac{V_{i}}{V_{T}} ; \Delta t_{n}=t_{n}-t_{n-1}
$$

\subsection{Analytical determinations}

All analytical determinations were performed on PTFE filtered samples $(0.22 \mu \mathrm{m})$. MET levels were monitored by reverse-phase liquid chromatography coupled to UV detection using a HPLC-UV system (Agilent Technologies, series 1100). The mobile phase used consisted of a linear gradient of a mixture of acetonitrile/water with formic acid (25 mM) (10/90, initial conditions) and the stationary phase was a Gemini $C_{18}$ column $(150 \times 3 \mathrm{~mm}, 5 \mu \mathrm{m})$ from Phenomenex (CA, USA). UV detection of MET was done at $\lambda=200.4 \mathrm{~nm}$. Mineralization was 
evaluated by measuring the dissolved organic carbon (DOC) of filtered water samples with a Shimadzu-5050A TOC analyzer, which was calibrated with standard solutions of potassium hydrogen phthalate. Ammonium concentration was determined with a Dionex DX-120 ion chromatograph (IC) equipped with a Dionex lonpac CS12A 4x250 mm column. Anion concentrations $\left(\mathrm{NO}_{3}^{-}\right.$and carboxylates) were measured with a Dionex DX-600 ion chromatograph using a Dionex lonpac AS11-HC 4x250 mm column.

In order to ensure that the photo-Fenton reactions take place, $\mathrm{Fe}^{2+} / \mathrm{Fe}^{3+}$ and $\mathrm{H}_{2} \mathrm{O}_{2}$ must be continuously present in the system. In this respect, and following ISO 6332, total iron concentration was monitored in water samples by colorimetric determination with 1,10phenanthroline using a Unicam-2 spectrophotometer. The concentration of $\mathrm{H}_{2} \mathrm{O}_{2}$ was analyzed by means of a fast and simple spectrophotometric method, which is based on the measure of the red orange peroxovanadium cation formed when $\mathrm{H}_{2} \mathrm{O}_{2}$ reacts with ammonium metavanadate (Nogueira et al., 2005). After evaluating MET transformation kinetics with the photo-Fenton treatment, a controlled photo-Fenton reaction was performed by adding periodically small amounts of $\mathrm{H}_{2} \mathrm{O}_{2}(0.01 \mathrm{mM})$ to the system. Samples used to identify phototransformation products and to perform the toxicity studies were collected once the added amount of $\mathrm{H}_{2} \mathrm{O}_{2}$ was consumed.

Samples used to identify phototransformation products were 20-fold concentrated by means of solid phase extraction (SPE) with a Baker vacuum system (J.T. Baker, The Netherlands) onto previously conditioned $(5 \mathrm{~mL}$ of $\mathrm{MeOH}$ and $5 \mathrm{~mL}$ of demineralized water) Oasis HLB cartridges (6cc/200 mg, $30 \mu \mathrm{m})$ (Waters, Milford, MA). Analyte elution was performed with $4 \mathrm{~mL}+4 \mathrm{~mL}$ of $\mathrm{MeOH}$. The eluted volume was dried under $\mathrm{N}_{2}$ and then reconstituted to $1 \mathrm{~mL}$ with water/MeOH $(90 / 10, \mathrm{v} / \mathrm{v})$.

Identification of phototransformation products generated during the different treatments was performed by means of UPLC-QqTOF-MS/MS using a Waters Acquity UPLC ${ }^{\text {TM }}$ system coupled 
to a Waters/Micromass QqToF-Micro ${ }^{\mathrm{TM}}$ (Waters/Micromass, Manchester, UK). Chromatographic separation was performed on a Waters Acquity BEH $C_{18}$ column $(2.1 \times 100 \mathrm{~mm}, 1.7 \mu \mathrm{m})$ that was kept in a column oven at $30^{\circ} \mathrm{C}$. The mobile phase consisted of a linear gradient of $\mathrm{A}$ : acetonitrile and $\mathrm{B}: 25 \mathrm{mM}$ aqueous formic acid for analyses performed in positive electrospray ionization (PI) mode. A linear gradient of $\mathrm{A}$ : acetonitrile and $\mathrm{B}$ : water was applied for analyses carried out in the negative ionization (NI) mode. Full-scan analyses carried out on selected samples in $\mathrm{NI}$ mode did not show significant peaks compared to blank samples, thus further MS and $\mathrm{MS}^{2}$ analyses were performed in the PI mode. Acquisition in full scan mode was performed with a capillary voltage of $3000 \mathrm{~V}$ in the range $\mathrm{m} / \mathrm{z} 50-700$ at different cone voltages $(15 \mathrm{~V}, 25 \mathrm{~V}$ and 35 V) to look for potential generation of dimers. Dimerization of the organic compound or its phototransformation products has been previously observed during phototransformation experiments (Konstantinou et al., 2010). $\mathrm{MS}^{2}$ analyses at different collision energies (10-40 eV) were carried out on identified protonated molecules $\left[\mathrm{M}+\mathrm{H}^{+}\right]$in order to get structural information. The collision gas applied in the fragmentation cell was argon. Data were collected in the centroid mode, with a scan time of $0.3 \mathrm{~s}$ and an interscan delay time of $0.1 \mathrm{~s}$, and with a full width at half maximum (FWHM) resolution of 5000 . Other MS parameters were set as follows: $600 \mathrm{~L} / \mathrm{h}$ for the desolvation gas at a temperature of $350{ }^{\circ} \mathrm{C}, 50 \mathrm{~L} / \mathrm{h}$ for the cone gas, $120{ }^{\circ} \mathrm{C}$ as source temperature. A valine-tyrosine-valine (Val-Tyr-Val) solution $\left(\mathrm{m} / \mathrm{z}\right.$ of $\left.[\mathrm{M}+\mathrm{H}]^{+}=380.2185\right)$ was used to tune the instrument and also as lock mass to achieve mass accuracy. Elemental compositions and accurate masses of the protonated molecules and their fragments were determined by means of MassLynx V4.1 software.

\subsection{Acute toxicity evaluation}

Acute toxicity of MET and their solar phototransformation products was evaluated on selected not preconcentrated samples with Biofix ${ }^{\circledR}$ Lumi-10, a commercial bioassay based on inhibition of the bioluminescence emitted by the marine bacteria Vibrio fischeri. The inhibition of light emission was measured after sample contact periods of 5, 15 and $30 \mathrm{~min}$, as detailed in 
ISO 11348-3:2007. To avoid further transformation, the Fenton process was quenched by controlling the amount of $\mathrm{H}_{2} \mathrm{O}_{2}$ added to the system, as aforementioned. Quenching in samples collected during $\mathrm{TiO}_{2}$ photocatalysis and photolysis was achieved by filtration and storage in the dark at $4^{\circ} \mathrm{C}$ until toxicity evaluation (performed in less than 24 hours).

\section{RESULTS AND DISCUSSION}

\subsection{Methadone hydrolysis and photolysis}

No decrease on $\mathrm{MET}_{0}$ was observed after 22 hours of keeping DW and SWeff solutions in the dark at room temperature. On the contrary, $\mathrm{MET}_{0}$ was completely transformed during photolysis experiments, as it is shown in Figure 1. Note that $t_{30 w}$ was calculated using a variation of equation 1, where $V_{i} / V_{T}$ was equal to 1 as these experiments were performed in transparent beakers where the complete volume was illuminated. Direct sun-light exposure of MET solutions resulted in a decrease of more than $90 \%$ of $\mathrm{MET}_{0}$ after 10 and 17 hours of sun-light irradiation time in DW and SWeff matrices, respectively. Photolytic transformation rates of MET were considered negligible compared with photocatalytic transformation rates, because the photolytic transformation of $\mathrm{MET}_{0}$ requires much longer times (hours vs. min, see section 3.2).

MET transformation during photolysis is mainly derived by photonic reactions, since hydroxyl radicals are not produced and other so oxidant species, such as superoxide radicals, are unlikely to be generated because water solutions were not aerated. This statement is confirmed by the fact that DOC levels were stable throughout the entire photolysis experiments, which were run for up to 6 days ( $\approx 62$ hours of normalized irradiation time) in both investigated matrices, and phototransformation products differ to some extent from those generated during photocatalytic treatments (see section 3.4). 


\subsection{Solar photocatalysis}

\subsubsection{Heterogeneous photocatalysis with $\mathrm{TiO}_{2}$}

Phototransformation and mineralization of MET in DW and SWeff with $\mathrm{TiO}_{2}$ heterogeneous photocatalysis is shown in Figure 2a. After system homogenization and before starting the $\mathrm{TiO}_{2}$ photocatalytic treatment, a decrease in $\mathrm{MET}_{0}$ of about $7 \%$ and $10 \%$ was observed in $\mathrm{DW}$ and SWeff, respectively, due to adsorption of the compound onto the $\mathrm{TiO}_{2}$ particles.

MET was completely transformed in DW after 23 min of solar photocatalytic treatment whereas 13 min more were necessary for its complete transformation in SWeff. Overall, DOC mineralization occurred at a slower rate than compound transformation. In this respect it must be clarified that the $\mathrm{DOC}$ measured in SWeff $\left(\mathrm{DOC}_{0} \approx 30 \mathrm{mg} / \mathrm{L}\right)$ is mainly generated by the added peptone, meat extract and urea (see Table S1), substances that hide the mineralization behavior of MET in SWeff. On the other hand, more than $90 \%$ of the $\mathrm{DOC}\left(\mathrm{DOC}_{0} \approx 8 \mathrm{mg} / \mathrm{L}\right)$ present in DW, which is exclusively generated by the presence of MET, was mineralized.

\subsubsection{Homogeneous photocatalysis by photo-Fenton}

Transformation of MET in the investigated water matrices with photo-Fenton treatment is shown in Figure 2b. Phototransformation of MET with solar photo-Fenton was in general very fast. Only 4 min of photo-Fenton treatment were sufficient to transform completely $\mathrm{MET}_{0}$ in DW. Complete transformation of $\mathrm{MET}_{0}$ in SWeff required four times more of normalized irradiation time (16 min).

About $80 \%$ of DOC mineralization was achieved in DW containing MET after 75 min. The mineralization rate during photo-Fenton treatment was initially higher than with $\mathrm{TiO}_{2}$ heterogeneous photocatalysis. However, similar mineralization amounts were reached at the end of both photocatalytic treatments. In this respect, the mineralization curve in the photoFenton treatment of MET DW solutions reached a plateau at $80 \%$, which is slightly lower than 
that observed during heterogeneous photocatalysis with $\mathrm{TiO}_{2}(90 \%)$. Usually photo-Fenton is faster than $\mathrm{TiO}_{2}$ photocatalysis in $\mathrm{DOC}$ mineralization, but not necessarily higher mineralization levels are obtained, as it has been previously reported (Malato et al., 2002; Sirtori et al., 2009). This finding could be attributed to the formation of more recalcitrant carboxylic acids during the photo-Fenton treatments due to the formation of stable complexes with Fe (Pignatello et al., 2006). The same level of DOC mineralization was achieved in SWeff, compared with DW, but after more than two hours of photo-Fenton treatment (190 min). Mineralization of MET SWeff solutions with photo-Fenton was comparatively higher than with $\mathrm{TiO}_{2}$ photocatalysis, since the presence of $\mathrm{K}_{2} \mathrm{HPO}_{4}$, which is known to adsorb onto $\mathrm{TiO}_{2}$ particles, and $\mathrm{NaHCO}_{3}$, which is a hydroxyl radical scavenger which is absent during photo-Fenton treatment due to acidic $\mathrm{pH}$, inhibits mineralization efficiency of the $\mathrm{TiO}_{2}$ photocatalytic treatment. Other inorganic components present in the SWeff matrix, such as sulphate and chloride, which also behave as $\mathrm{HO}^{\bullet}$ scavengers, affect the efficiency of both photocatalytic processes to the same extent.

\subsection{Kinetics of phototransformation reactions.}

The photocatalytic transformation of $\mathrm{MET}$ with $\mathrm{TiO}_{2}$ followed apparent first-order kinetics, as is usual in heterogeneous photocatalysis when initial concentration is low enough and no catalyst saturation occurs. Since phototransformation intermediates generated in the process could also be competitive on the surface of the $\mathrm{TiO}_{2}$ and their concentration, like MET concentration, changes throughout the reaction up to their mineralization, the transformation process follows a Langmuir-Hinshelwood type mechanism and reaction kinetics could be described by equation 2 (Herrmann, 1999):

$$
\mathrm{r}=\frac{k_{r} K C}{1+K C+\sum_{i=1}^{n} \mathrm{~K}_{\mathrm{i}} C_{i}(i=1, n)}
$$


where $k_{r}$ is the reaction rate constant, $K$ is the reactant (MET) adsorption constant, $C$ is MET concentration at any time, and $\mathrm{K}_{\mathrm{i}}$ and $\mathrm{C}_{\mathrm{i}}$ are the adsorption constant and the concentration at any time, respectively, of the phototransformation products $\mathrm{i}$. When $\mathrm{C}_{0}(10 \mathrm{mg} / \mathrm{L}$ of MET) is low enough, equation 2 can be simplified $(1+K C+\Sigma \ldots=1)$ to a first order reaction rate equation (see equation 3), which was also confirmed by the linear behavior of $\ln \left(C_{0} / C\right)$ as a function of $t_{30 w}$ :

$$
\mathrm{r}=k_{a p} C
$$

In the photo-Fenton treatment and working at such concentration of MET, the main reaction that governs the transformation of this compound is that happening between $\mathrm{HO}^{\bullet}$ and MET, being hydroxyl radicals at constant concentration. The concentration of $\mathrm{HO}^{\circ}$, like in heterogeneous photocatalytic treatments with $\mathrm{TiO}_{2}$, depends on the $\mathrm{Fe}$ concentration, which was maintained constant in all experiments, and the photons entering in the photoreactor. Using equation 1 the radiation entering the photoreactor was normalized. Based on the aforementioned, the rate equation of the photo-Fenton process can be written as:

$$
\mathrm{r}=k_{H O}\left[H O^{\bullet}\right] C=k_{a p}^{\prime} C
$$

where $\mathrm{C}$ is MET concentration, $\mathrm{k}_{\mathrm{HO}}$ is the photo-Fenton reaction rate constant and $\mathrm{k}_{\mathrm{ap}}$ is a pseudo first order constant that takes into consideration that under the commented experimental conditions, $\mathrm{HO}^{\bullet}$ concentration could be considered constant.

In the light of the results, and as it is shown in Table 1, it can be concluded that transformation of MET is faster with the photo-Fenton treatment than with $\mathrm{TiO}_{2}$ heterogeneous photocatalysis, being about four times and two times faster in DW and in SWeff water, respectively. This assessment is supported by the half-life time of $\mathrm{MET}$ observed in $\mathrm{TiO}_{2}$ heterogeneous photocatalysis experiments (3 $\mathrm{min}$ in DW and $8 \mathrm{~min}$ in SWeff) and in photoFenton experiments ( $0.5 \mathrm{~min}$ in DW and $4 \mathrm{~min}$ in SWeff). The observed results may be explained by the higher solar light harvesting that the photo-Fenton process presents as 
compared to $\mathrm{TiO}_{2}$ photocatalysis, which finally produces larger quantities of $\mathrm{HO}^{\bullet}$ in less time. In solar photo-Fenton treatments, the effective wavelength can reach up to $600 \mathrm{~nm}$ depending on the presence of different iron complexes, whereas in $\mathrm{TiO}_{2}$ photocatalysis it is below $390 \mathrm{~nm}$. Additionally, contrary to photo-Fenton treatments, in $\mathrm{TiO}_{2}$ photocatalysis, reactions do not take place in dark zones (Malato et al., 2009). As the mineralization does not follow simple models like first or zero order kinetics, overall rate constants cannot be calculated. Therefore, the normalized irradiation time necessary to mineralize $75 \%$ of the initial DOC was provided to compare experiments (see Table 1), and in this case, photo-Fenton was also more effective than $\mathrm{TiO}_{2}$ photocatalysis in compound mineralization.

Lower transformation and mineralization rates of the compound in SWeff compared to DW systems indicate the non-selective attack of $\mathrm{HO}^{\circ}$, which also react with other inorganic and organic species that are present in the SWeff, being the obtained kinetics more realistic than in DW experiments.

The formation of nitrogen inorganic species $\left(\mathrm{NH}_{4}{ }^{+}\right.$and $\left.\mathrm{NO}_{3}{ }^{-}\right)$and carboxylic acids produced from MET transformation was monitored by IC during the photocatalytic treatments carried out with DW. These measurements were not performed in SWeff experiments, as the chemical composition of this matrix will interfere in the results obtained. In the light of the results, the heteroatoms present in the molecule of MET were released as $\mathrm{NH}_{4}{ }^{+}$and $\mathrm{NO}_{3}{ }^{-}$. During photocatalytic treatments of MET aqueous solutions initial $\mathrm{NO}_{3}{ }^{-}$levels $(<0.6 \mathrm{mg} / \mathrm{L})$ increased up to $1.17 \mathrm{mg} / \mathrm{L}$ by the end of the experiments, whereas initial $\mathrm{NH}_{4}{ }^{+}$levels increased from levels below $0.1 \mathrm{mg} / \mathrm{L}$ to $0.4 \mathrm{mg} / \mathrm{L}$. Taking into account that MET contains one atom of $\mathrm{N}$ and that 10 $\mathrm{mg} / \mathrm{L}$ of MET $(0.45 \mathrm{mg} / \mathrm{L}$ of $\mathrm{N})$ were decomposed, it can be concluded that $80 \%$ of organic $\mathrm{N}$ was mineralized. Main carboxylic acids accumulated during these processes were oxalic acid and maleic acid, which reached levels up to $2 \mathrm{mg} / \mathrm{L}$. 


\subsection{Major phototransformation intermediates and phototransformation routes}

Identification of phototransformation intermediates of MET was performed on preconcentrated DW and SWeff samples rather than on non-preconcentrated ones because analysis in full scan of the former evidenced the existence of a greater number of peaks, and hence photo-transformation products, than the latter and also because the lower intensity of some of the phototransformation intermediates observed in non-preconcentrated samples affected negatively the mass accuracy of the results. Total ion current (TIC) chromatograms obtained after full-scan MS analyses of representative preconcentrated DW samples are shown as supplementary information in Figure S1. Experimental and theoretical masses $(\mathrm{m} / \mathrm{z})$, the error between them in $\mathrm{mDa}$ and $\mathrm{ppm}$, the double bond equivalent (DBE), and the proposed elemental composition of the protonated phototransformation intermediates and their main fragment ions formed during phototransformation of MET are shown in Table 2. The calculated accurate masses of parent ions, which were present in all cases in their protonated form $[\mathrm{M}+\mathrm{H}]^{+}$, were obtained by constraining molecule elements as follows: C: $0-45, \mathrm{H}: 0-80, \mathrm{~N}: 0-2$, O:0-8. A tolerance of $\pm 5 \mathrm{ppm}$ in the error between the measured and the calculated accurate mass was considered in all but a few cases (where it was slightly higher) in order to guarantee the correct assignment of the molecular formula of major ions (Ferrer and Thurman, 2003). The evolution of the most abundant phototransformation intermediates is shown in Figure 3. During solar photolysis, photointermediates levels continually increase as the $\mathrm{MET}_{0}$ decreases, whereas during solar photocatalysis, the highest levels of photointermediates were observed when more than half of the $\mathrm{MET}_{0}$ was transformed and they were readily phototransformed afterwards.

Overall, all identified phototransformation intermediates of MET were present in both investigated aqueous matrices. However, some of them were exclusively generated by one of the investigated treatments, as it has been indicated in Table 2. In this respect, up to four isobaric compounds (P309) were identified in water samples collected only during solar 
photolysis. The protonated molecule of these compounds presented the same exact mass, and in consequence, the same molecular formula, than the protonated molecule of MET $\left([\mathrm{M}+\mathrm{H}]^{+}=310.2168, \mathrm{C}_{21} \mathrm{H}_{28} \mathrm{NO}\right)$. However, as it is shown in Figure 4, the fragmentation patterns of those compounds labeled as P309 $\left(t_{R}=5.36,5.49,5.54\right.$ and 5.67$)$ are different from that observed for MET ( $\left.t_{R}=5.98\right)$ at a given collision energy, e.g., $20 \mathrm{eV}$, whose identity was confirmed with the analysis of a MET standard solution. The fragmentation of MET was characterized by the presence of two main fragment ions with calculated exact masses of $\mathrm{m} / \mathrm{z}$ 265.1592 and 105.0340 as main fragments ions, which gave as best fit formula $\mathrm{C}_{19} \mathrm{H}_{21} \mathrm{O}$ and $\mathrm{C}_{7} \mathrm{H}_{5} \mathrm{O}$, respectively. The ion at $\mathrm{m} / \mathrm{z} 265$ corresponds to the loss of dimethylamine $\left(\mathrm{HN}\left(\mathrm{CH}_{3}\right)_{2}\right.$, 45 uma), whereas the ion at $\mathrm{m} / \mathrm{z} 105$ is believed to correspond to a benzoyl cation formed after structural reordering (Joyce et al., 2004). Fragmentation of the isobaric compounds at $t_{R}=5.36$, 5.49, 5.54 and 5.67 resulted in the ion at $m / z 223.1123\left(\mathrm{C}_{16} \mathrm{H}_{15} \mathrm{O}\right)$ as main fragment ion. This ion, which may result from the sequential loss of dimethylamine and the alkene $\mathrm{CH}_{2}=\mathrm{CHCH}_{3}$ was also present in the fragmentation spectrum of MET, but at a lower intensity (Joyce et al., 2004). The fragmentation of some of the compounds labeled as P309 favors also the formation of ions present in the MET spectrum, such as $m / z 265$ and $m / z 247.1487\left(\mathrm{C}_{9} \mathrm{H}_{19}\right)$, the latter generated by further loss of a molecule of $\mathrm{H}_{2} \mathrm{O}$. Thus, similarities in the fragmentation spectra of the compounds labeled as P309 and that obtained for MET suggest that compounds P309 are positional isomers of MET.

The protonated molecule of P277, compound generated during all investigated treatments presented an accurate mass of $\mathrm{m} / \mathrm{z} 278.1915$ (calculated exact mass of $\mathrm{m} / \mathrm{z}$ 278.1909), which gave the best fit molecular formula $\mathrm{C}_{20} \mathrm{H}_{24} \mathrm{~N}$. This compound was identified as EDDP, one of the main urinary metabolites of MET (Ferrari et al., 2004; Goldstein and Brown, 2003) and its identity was confirmed with the MS and MS/MS analysis of a standard solution of EDDP, as it is shown in Figure $\mathrm{S} 2$ as supplementary information. 
The phototransformation product P263 was observed only in water samples collected during photocatalytic processes. The calculated exact mass of its protonated molecule, obtained with an error below 5 ppm, $\mathrm{m} / \mathrm{z}=264.1752\left(\mathrm{C}_{19} \mathrm{H}_{22} \mathrm{~N}\right)$, fits with another urinary metabolite of MET, 2-ethylidene-1,5-dimethyl-3,3-diphenylpyrrolidine (EMDP), which is a demethylated form of EDDP. The main ions observed during its fragmentation $(\mathrm{m} / \mathrm{z} 235$ y $\mathrm{m} / \mathrm{z}$ 220) correspond to the sequential loss of an ethyl and a methyl group, thus following the same fragmentation pattern as EDDP (see Table 2), and confirm previously published findings (Kelly et al., 2005).

During the investigated photolytic and photocatalytic treatments, up to four isobaric compounds, labeled as P293, whose protonated molecule presents a calculated exact mass of $m / z$ of 294.1585 that corresponds to the molecular formula $\mathrm{C}_{20} \mathrm{H}_{24} \mathrm{NO}$, were also formed (see Table 2). Note that these phototransformation products are generated with less intensity during photolysis than during photocatalysis. Their fragmentation spectra, the molecular formula of their protonated form and the fragment ions generated during $\mathrm{MS}^{2}$ analysis (shown as supplementary material in Figures S3 and S4) suggest that they are monohydroxilated derivatives of EDDP. The main fragment ions observed during MS/MS analyses of the protonated molecule of the P293 compounds, $m / z 265.1467-\mathrm{C}_{18} \mathrm{H}_{19} \mathrm{NO}$ and $m / z 250.1232-$ $\mathrm{C}_{17} \mathrm{H}_{16} \mathrm{NO}$, as well as the parent ion, are similar to those observed for EDDP plus 16 uma, i.e., an oxygen atom (see Figures S2 and S4). Despite the fact that the fragmentation spectra obtained do not allow identifying the exact position of the $\mathrm{OH}$ group in the molecules, hydroxylation seems to occur at the phenyl groups of EDDP. This assessment is supported by the presence of the fragment ion with $m / z 186.1283-\mathrm{C}_{13} \mathrm{H}_{16} \mathrm{~N}$, which could be generated by the sequential loss of a methyl group and a hydroxylated phenyl group. .

The investigated treatments also generated monohydroxylated (P325) and dihydroxylated (P341) derivatives of MET. Concerning monohydroxylated species, several isobaric compounds with $\mathrm{m} / \mathrm{z} 326.2120\left(\mathrm{C}_{21} \mathrm{H}_{28} \mathrm{NO}_{2}\right)$ were detected, and the fragmentation 
spectra and fragmentation pathway of the most intense $\mathrm{m} / \mathrm{z} 326$ ions have been provided as supplementary material in Figure S5. These compounds are also the major phototransformation products generated during the investigated treatments (see Figure 3 and Figure S1). MS/MS analyses of $\mathrm{P} 325$ revealed ions at $m / z 281.1542-\mathrm{C}_{19} \mathrm{H}_{21} \mathrm{O}_{2}$ and $239.1072-\mathrm{C}_{16} \mathrm{H}_{15} \mathrm{O}_{2}$ as major fragments. These fragment ions correspond to the main MET fragment ions with $\mathrm{m} / \mathrm{z} 265$ and $\mathrm{m} / \mathrm{z} 223$ plus an additional atom of oxygen (16 uma) (see Table 2). Additionally, the presence of the fragment ions at $m / z 105$ (major fragment ion of MET) and $m / z 121$ (105+16 um), which could correspond to a benzoyl cation (Castiglioni et al., 2008) and a hydroxybenzoyl cation, respectively, may indicate that the $\mathrm{HO}^{\circ}$ attack (in the case of photocatalytic treatments) took place at one of the phenyl groups of the molecule.

Despite the fact that dihydroxylated derivatives of MET, labeled as P341, were also found in water samples collected during MET photolysis, they were generated with higher intensity during photocatalytic treatments (see Figure 3 and Figure S1). Up to three isobaric compounds presented a calculated exact mass of $m / z 342.2069\left([\mathrm{M}+\mathrm{H}]^{+}-\mathrm{C}_{21} \mathrm{H}_{28} \mathrm{NO}_{3}\right)$ in all cases with an error below $5 \mathrm{ppm}$. MS/MS analyses showed the ion at $\mathrm{m} / \mathrm{z} 121$ as major fragment ion. As it was discussed for compounds P325, this fragment ion is indicative of a hydroxylated phenyl group. Therefore, with the structural information obtained (fragmentation spectra shown as supplementary material in Figure S6), it is possible to predict that one of the $\mathrm{HO}^{\circ}$ attacks occurred at one of the phenyl groups of the molecule. However, MS/MS analyses do not provide enough information to assess that the other $\mathrm{HO}^{\circ}$ attack may have taken place at the other phenyl group or in another part of the molecule because other major fragments were obtained $\left(m / z 297.1491-\mathrm{C}_{19} \mathrm{H}_{21} \mathrm{O}_{3}\right.$ and $\left.m / z 255.1030-\mathrm{C}_{16} \mathrm{H}_{15} \mathrm{O}_{3}\right)$, which corresponded to main MET fragment ions plus two atoms of oxygen $(\mathrm{m} / \mathrm{z} 265+32$ and $\mathrm{m} / \mathrm{z} 223+32)$.

Figure 5 shows the main proposed phototransformation pathways of MET during solar photocatalytic treatments. Considering the identified photointermediates and their abundance, the primary phototransformation route would lead to the multistep hydroxylation of MET (P325 y 
P341) via $\mathrm{HO}^{\circ}$ attack. Multi-step hydroxylations were also identified as one of the main photocatalytic transformation route of COC in aqueous solutions (Postigo et al., 2011). Further transformation would proceed through fragmentation and cyclisation of MET (EDDP y EMDP). Reisch and Schildgen reported that MET in its solid form or in aqueous solution reacts in presence of UV light mainly via fragmentation which produces propionaldehyde $\left(\mathrm{C}_{2} \mathrm{H}_{5} \mathrm{CHO}\right)$ and $\mathrm{N}, \mathrm{N}$-dimethyl-4,4,-diphenylbut-3-en-2-amine $\left([\mathrm{M}+\mathrm{H}]^{+}=251.1674\right.$ uma $\left.-\mathrm{C}_{18} \mathrm{H}_{21} \mathrm{~N}\right)$, and cyclisation, which generates 2-ethylideno-5-methyl-3,3-diphenyl-tetrahidrofurano $\left([\mathrm{M}+\mathrm{H}]^{+}=\right.$ 264.1514 uma $-\mathrm{C}_{19} \mathrm{H}_{20} \mathrm{O}$ ) (Reisch and Schildgen, 1972a; b). However, these compounds were not found in the investigated samples by means of UPLC-ESI-QqToF-MS/MS, perhaps because they were not retained in SPE or they could be formed but also rapidly degraded by $\mathrm{HO}^{*}$. Identified phototransformation routes of MET in DW and in SWeff were equal. Further transformation of most of these compounds into aliphatic products, e.g., carboxylic acids before complete mineralization would imply cleavage of their benzene rings. Dimmers of MET or its identified phototransformation products were not observed to be formed in any case.

\subsection{Toxicity evaluation}

The acute toxicity of MET and its phototransformation intermediates was monitored with the $V$. fischeri toxicity test. Bioluminescence inhibition percentages obtained in selected DW samples during the photolysis, heterogeneous photocatalysis with $\mathrm{TiO}_{2}$ and photo-Fenton are shown in Figure 6 . Bioluminescence inhibition values were usually below $30 \%$, which indicates that MET and its intermediates have low acute toxicity effects on the tested bacteria. Overall, higher inhibition percentages were obtained in DW samples compared to SWeff samples, where stimulation percentages were mainly observed. This fact may be attributed to the higher content of organic matter in SWeff than in DW, which may be available for the cells as a food resource. In the light of the results, bioluminescence emitted by the bacteria seemed to be more inhibited during photolysis than in solar photocatalytic treatments. As it is shown in Figure 6, complete 
disappearance of MET did not have a strong influence on inhibition percentage, which points out the generated photointermediates as the main responsible for bioluminescence inhibition. This is also confirmed by the initial samples (SO), which only contained MET and did not inhibit the bacterial bioluminescence and by comparing the evolution of the generated photointermediates (see Figures 3 and 6). On one hand, many photo-intermediates generated during photolysis were not further transformed and thus, they, and their associated toxicity, remained in solution at the end of the treatment. On the other hand, photo-intermediates generated during photocatalytic treatments are completely transformed and substantially mineralized at the end of the treatment, which is in agreement with the disappearance of the acute toxicity. Photo-Fenton treatment seems to produce less acute toxic effects. However, since the same photointermediates were identified during both photocatalytic treatments, this fact may be attributed to the rapid transformation of the most harmful chemical species during photo-Fenton treatment, or to the generation of more toxic, still unidentified, species during $\mathrm{TiO}_{2}$ photocatalysis.

\section{CONCLUSIONS}

MET in aqueous solutions did not experience hydrolysis, but it was substantially transformed in the presence of solar irradiation. Compared with direct solar photolysis, transformation rate of MET in aqueous solutions was highly increased with the solar photocatalytic processes investigated i.e. photo-Fenton and heterogeneous photocatalysis with $\mathrm{TiO}_{2}$ (min vs hours). Among the studied photocatalytic treatments, photo-Fenton was observed to be slightly more efficient than $\mathrm{TiO}_{2}$ photocatalysis in MET transformation and mineralization. This work confirms that the studied AOPs are good alternatives to decontaminate waters containing MET. The use of natural solar irradiation increases the cost-effectiveness of photocatalytic processes, and thus, facilitates their potential application. 
MET transformation rates observed in SWeff are more realistic than those observed in DW, since other chemical species are present in solution and also react with the generated $\mathrm{HO}^{\circ}$. However, lower transformation rates may be expected in real waters with high organic carbon loads. The presence of natural organic matter should not affect to the transformation pathway here reported, though other transformation routes may also take place due to the formation of reactive oxygen species (ROS) other than $\mathrm{HO}^{\circ}$. However, in this respect, it is important to remark that the formation of ROS during AOPs is minor compared to the production of $\mathrm{HO}^{\circ}$ radicals.

Additionally, the treatment of lower MET initial concentrations would benefit the transformation rates and would result in less toxic treated samples, since the amount of phototransformation products generated will be also reduced.

\section{ACKNOWLEDGMENTS}

The research leading to these results has received funding from the European Community's Seventh Framework Programme ([FP7/2007-2013]) under grant agreement n. 265264, the Spanish Ministry of Science and Innovation through the projects SCARCE (Consolider-Ingenio 2010 CSD2009-00065) and CEMAGUA (CGL2007-64551/HID), and the "Programa de Acceso y Mejora de Grandes Instalaciones Cientificas Españolas" (Plataforma Solar de Almería, GIC-05-17). It reflects only the author's views. The Community is not liable for any use that may be made of the information contained therein. Cristina Postigo acknowledges the European Social Fund and AGAUR (Generalitat de Catalunya, Spain) for their economical support through the FI pre-doctoral grant. Carla Sirtori wishes to thank the CAPES foundation- 
Ministry of Education for the Ph.D. Research grant (BEX Processo: 37630-05-6). Special thanks to Agustin Carrión and Elisa Ramos for assistance during experiments execution.

\section{REFERENCES}

Berset, J.D., Brenneisen, R. and Mathieu, C. (2010) Analysis of licit and illicit drugs in waste, surface and lake water samples using large volume direct injection high performance liquid chromatography - Electrospray tandem mass spectrometry (HPLC-MS/MS). Chemosphere 81(7), 859-866.

Boleda, M.R., Galcerán, M.T. and Ventura, F. (2007) Trace determination of cannabinoids and opiates in wastewater and surface waters by ultra-performance liquid chromatography-tandem mass spectrometry. Journal of Chromatography A 1175(1), 38-48.

Boleda, M.R., Galceran, M.T. and Ventura, F. (2009) Monitoring of opiates, cannabinoids and their metabolites in wastewater, surface water and finished water in Catalonia, Spain. Water Research 43(4), 1126-1136.

Castiglioni, S., Zuccato, E., Chiabrando, C., Fanelli, R. and Bagnati, R. (2008) Mass spectrometric analysis of illicit drugs in wastewater and surface water. Mass Spectrometry Reviews 27(4), 378-394.

Castiglioni, S. and Zuccato, E. (2010) Illicit drugs in the environment: Emerging contaminants and indicators of drug abuse. Integrated Environmental Assessment and Management 6(1), 186-187. 
Fatta-Kassinos, D., Meric, S. and Nikolau, A. (2011) Pharmaceutical residues in environmental waters and wastewaters: current state of knowledge and future research. Analytical and Bioanalytical Chemistry 399(1), 251-275.

Ferrari, A., Coccia, C.P.R., Bertolini, A. and Sternieri, E. (2004) Methadone - metabolism, pharmacokinetics and interactions. Pharmacological Research 50(6), 551-559.

Ferrer, I. and Thurman, E.M. (2003) Liquid chromatography/time-of-flight/mass spectrometry (LC/TOF/MS) for the analysis of emerging contaminants Trends in Analytical Chemistry 22(10), 750-756.

Goldstein, A. and Brown, B.W. (2003) Urine testing in methadone maintenance treatment: applications and limitations. Journal of Substance Abuse Treatment 25(2), 61-63.

Herrmann, J.M. (1999) Heterogeneous photocatalysis: fundamentals and applications to the removal of various types of aqueous pollutants. Catalysis Today 53(1), 115-129.

Joyce, C., Smyth, W.F., Ramachandran, V.N., O'Kane, E. and Coulter, D.J. (2004) The characterisation of selected drugs with amine-containing side chains using electrospray ionisation and ion trap mass spectrometry and their determination by HPLC-ESI-MS. Journal of Pharmaceutical and Biomedical Analysis 36(3), 465-476.

Kelly, T., Doble, P. and Dawson, M. (2005) Chiral analysis of methadone and its major metabolites (EDDP and EMDP) by liquid chromatography-mass spectrometry. Journal of Chromatography B 814(2), 315-323.

Klavarioti, M., Mantzavinos, D. and Kassinos, D. (2009) Removal of residual pharmaceuticals from aqueous systems by advanced oxidation processes. Environment International 35(2), $402-$ 417. 
Konstantinou, I.K., Lambropoulou, D.A. and Albanis, T.A. (2010) Xenobiotics in the Urban Water Cycle: Mass Flows, Environmental Processes, Mitigation and Treatment Strategies Environmental Pollution. Fatta-Kassinos, D., Bester, K. and Kümmerer, K. (eds), pp. 179-194, Springer Netherlands.

Legrini, O., Oliveros, E. and Braun, A.M. (1993) Photochemical processes for water treatment. Chemical Reviews 93(2), 671-698.

Malato, S., Blanco, J., Cáceres, J., Fernández-Alba, A.R., Agüera, A. and Rodríguez, A. (2002) Photocatalytic treatment of water-soluble pesticides by photo-Fenton and $\mathrm{TiO}_{2}$ using solar energy. Catalysis Today 76(2-4), 209-220.

Malato, S., Blanco, J., Vidal, A., Alarcón, D., Maldonado, M.I., Cáceres, J. and Gernjak, W. (2003) Applied studies in solar photocatalytic detoxification: An overview. Solar Energy 75(4), 329-336.

Malato, S., Fernández-lbáñez, P., Maldonado, M.I., Blanco, J. and Gernjak, W. (2009) Decontamination and disinfection of water by solar photocatalysis: Recent overview and trends. Catalysis Today 147(1), 1-59.

Nogueira, R.F.P., Oliveira, M.C. and Paterlini, W.C. (2005) Simple and fast spectrophotometric determination of $\mathrm{H}_{2} \mathrm{O}_{2}$ in photo-Fenton reactions using metavanadate. Talanta 66(1), 86-91.

OECD (2001) Test No. 303: Simulation Test - Aerobic Sewage Treatment - A: Activated Sludge Units ; B: Biofilms. OECD Guidelines for the Testing of Chemicals, Section 3: Degradation and Accumulation. OECD Publishing, Paris. Available at: http://www.oecdilibrary.org/environment/test-no-303-simulation-test-aerobic-sewage-treatment-a-activatedsludge-units-b-biofilms_9789264070424-en, accessed in May 2011. 
Pignatello, J.J., Oliveros, E. and A., M. (2006) Advanced oxidation processes for organic contaminant destruction based on the Fenton reaction and related chemistry. Critical Reviews in Environmental Science Technology 36(1), 1-84.

Postigo, C., Sirtori, C., Oller, I., Malato, S., Maldonado, M.I., López De Alda, M.J. and Barceló, D. (2011) Solar transformation and photocatalytic treatment of cocaine in water: Kinetics, characterization of major intermediate products and toxicity evaluation. Applied Catalysis B: Environmental 104(1-2), 37-48.

Reisch, J. and Schildgen, R. (1972a) Light-induced fragmentation of D-(-)-methadone hydrochloride in aqueous solution. Archiv der Pharmazie 305, 40-48.

Reisch, J. and Schildgen, R. (1972b) Photolysis of crystalline D-(-)-methadone hydrochloride; radiolysis of aqueous solutions of D-(-)-methadone hydrochloride. Archiv der Pharmazie 305, 49-53.

Sirtori, C., Zapata, A., Malato, S., Gernjak, W., Fernández-Alba, A.R. and Agüera, A. (2009) Solar photocatalytic treatment of quinolones: Intermediates and toxicity evaluation. Photochemical and Photobiological Sciences 8(5), 644-651.

Terzic, S., Senta, I. and Ahel, M. (2010) Illicit drugs in wastewater of the city of Zagreb (Croatia) - Estimation of drug abuse in a transition country. Environmental Pollution 158(8), 2686-2693.

USEPA (2002) Methods for Measuring the Acute Toxicity of Effluents and Receiving Waters to Freshwater and Marine organisms. EPA-821-R-02-012. USEPA, Washington D.C. Available at: http://water.epa.gov/scitech/methods/cwa/wet/upload/2007 0710 methods wet disk2 atx.pdf , accessed in May 2011. 


\section{List of Figures}

Figure 1. MET transformation $\left(\mathrm{MET} / \mathrm{MET}_{0}\right)$ and mineralization $\left(\mathrm{DOC} / \mathrm{DOC}_{0}\right)$ during photolysis experiments performed in DW and SWeff. $\left({ }^{*}\right.$ the normalized illumination time $\left(t_{30 \mathrm{w}}\right)$ was calculated with a variation of equation 1 , where $V_{i} / V_{T}=1$ )

Figure 2. MET transformation (MET/MET $)_{0}$ ) and mineralization (DOC/DOC ${ }_{0}$ ) during a) heterogeneous photocatalysis with $\mathrm{TiO}_{2}$ and b) homogeneous photocatalysis by photo-Fenton in DW and SWeff ( $t_{30 w}$ : normalized illumination time, see equation 1$)$.

Figure 3. Time evolution of the major phototransformation intermediates of MET generated in DW during: a) hydrolysis (shadowed part) and solar photolysis, b) solar heterogeneous photocatalysis with $\mathrm{TiO}_{2}$ and c) solar photo-Fenton ( $t_{30 \mathrm{w}}$ : normalized illumination time, in the case of photolysis it was calculated with a variation of equation 1 where $V_{i} / V_{T}=1$ and in the case of photocatalysis with $\mathrm{TiO}_{2}$ and solar photo-Fenton it was calculated with equation 1).

Figure 4. Chromatogram and spectra obtained with MS/MS experiments of $\mathrm{m} / \mathrm{z} 310$ at a collision energy of $20 \mathrm{eV}$ in a DW sample collected during the solar photolysis experiment.

Figure 5. Proposed phototransformation pathway of MET in aqueous solution during solar photocatalytic treatments (MET: methadone, EDDP: 2-ethylidene- 1,5-dimethyl-3,3diphenylpyrrolidine, EMDP: 2-ethylidene-1,5-dimethyl-3,3-diphenylpyrrolidine, $\quad$ OH-MET: hydroxymethadone). * Identity confirmed with the analysis of a commercial analytical standard solution.

Figure 6. Inhibition of $V$. fischeri bioluminescence (\%) after $30 \mathrm{~min}$ of contact with selected DW samples collected during a) solar photolysis, b) solar heterogeneous photocatalysis, and c) photo-Fenton experiments. (White dots indicate the DOC of each sample). 
Table 1. Kinetic parameters obtained for phototransformation of MET in DW and SWeff with solar photocatalytic treatments $\left(\mathrm{k}_{\mathrm{ap}}\right.$ : pseudo-first order reaction rate constant and $\mathrm{r}^{2}$ : coefficient of determination, $\mathrm{t}_{30 \mathrm{w}}, 75 \% \mathrm{DOC}$ : normalized irradiation time required to mineralize $75 \%$ of the initial DOC)

\begin{tabular}{|c|c|c|c|c|c|c|}
\hline & \multirow{2}{*}{\multicolumn{3}{|c|}{ DW }} & \multirow{2}{*}{\multicolumn{3}{|c|}{ SWeff }} \\
\hline & & & & & & \\
\hline & $k_{a p}\left(\min ^{-1}\right)$ & $r^{2}$ & $\mathrm{t}_{30 \mathrm{w}, 75 \% \mathrm{DOC}}(\mathrm{min})$ & $k_{a p}\left(\min ^{-1}\right)$ & $r^{2}$ & $\mathrm{t}_{30 \mathrm{w}, 75 \% \mathrm{DOC}}(\mathrm{min})$ \\
\hline $\mathrm{TiO}_{2}$ Photocatalysis & 0.227 & 0.9761 & 55 & 0.110 & 0.9653 & $>200$ \\
\hline Photo-Fenton & 1.034 & 0.9739 & 50 & 0.264 & 0.972 & 170 \\
\hline
\end{tabular}


Table 2. Accurate mass measurement of protonated molecules and fragment product ions of MET and its phototransformation intermediates obtained with UPLC-ESI-QqTOF-MS/MS analyses.

\begin{tabular}{|c|c|c|c|c|c|c|c|c|}
\hline \multirow{2}{*}{ Comp ${ }^{a}$. } & \multirow{2}{*}{$\begin{array}{c}t_{R} \\
(\min )\end{array}$} & \multirow{2}{*}{$\begin{array}{l}\text { Precursor ion } \\
\text { Product ion }\end{array}$} & \multirow{2}{*}{$\begin{array}{l}\text { Molecular } \\
\text { formula }\end{array}$} & \multicolumn{2}{|c|}{ Mass $(\mathrm{m} / \mathrm{z})$} & \multicolumn{2}{|c|}{ Error } & \multirow{2}{*}{ DBE } \\
\hline & & & & Experimental & Calculated & $(\mathrm{mDa})$ & $\overline{(\mathrm{ppm})}$ & \\
\hline \multirow[t]{5}{*}{ MET } & 5.98 & {$[\mathrm{M}+\mathrm{H}]^{+}$} & $\mathrm{C}_{21} \mathrm{H}_{28} \mathrm{NO}$ & 310.2168 & 310.2171 & -0.3 & -1.0 & 8.5 \\
\hline & & {$\left[\mathrm{M}+\mathrm{H}-\mathrm{C}_{2} \mathrm{H}_{7} \mathrm{~N}\right]^{+}$} & $\mathrm{C}_{19} \mathrm{H}_{21} \mathrm{O}$ & 265.1604 & 265.1592 & 1.2 & 4.5 & 9.5 \\
\hline & & {$\left[\mathrm{M}+\mathrm{H}-\mathrm{C}_{5} \mathrm{H}_{13} \mathrm{~N}\right]^{+}$} & $\mathrm{C}_{16} \mathrm{H}_{15} \mathrm{O}$ & 223.1131 & 223.1123 & 0.8 & 3.6 & 9.5 \\
\hline & & {$\left[\mathrm{M}+\mathrm{H}-\mathrm{C}_{14} \mathrm{H}_{23} \mathrm{~N}\right]^{+}$} & $\mathrm{C}_{7} \mathrm{H}_{5} \mathrm{O}$ & 105.0344 & 105.0340 & 0.4 & 3.8 & 5.5 \\
\hline & & {$\left[\mathrm{M}+\mathrm{H}-\mathrm{C}_{14} \mathrm{H}_{2 I} \mathrm{NO}\right]^{+}$} & $\mathrm{C}_{7} \mathrm{H}_{7}$ & 91.0551 & 91.0548 & 0.3 & 3.3 & 4.5 \\
\hline *P263 & 5.68 & {$[\mathrm{M}+\mathrm{H}]^{+}$} & $\mathrm{C}_{19} \mathrm{H}_{22} \mathrm{~N}$ & 264.1759 & 264.1752 & 0.7 & 2.6 & 9.5 \\
\hline \multirow[t]{2}{*}{ EMDP } & & {$\left[\mathrm{M}+\mathrm{H}-\mathrm{C}_{2} \mathrm{H}_{5}\right]^{\cdot}$} & $\mathrm{C}_{17} \mathrm{H}_{17} \mathrm{~N}$ & 235.1353 & 235.1361 & -0.8 & -3.4 & 10.0 \\
\hline & & {$\left[\mathrm{M}+\mathrm{H}-\mathrm{CH}_{3}-\mathrm{C}_{2} \mathrm{H}_{5}\right]^{+}$} & $\mathrm{C}_{16} \mathrm{H}_{14} \mathrm{~N}$ & 220.1120 & 220.1126 & -0.6 & -2.7 & 10.5 \\
\hline$\overline{\mathbf{P 2 7 7}}$ & 5.45 & {$[\mathrm{M}+\mathrm{H}]^{+}$} & $\mathrm{C}_{20} \mathrm{H}_{24} \mathrm{~N}$ & 278.1915 & 278.1909 & 0.6 & 2.2 & 9.5 \\
\hline \multirow[t]{3}{*}{ EDDP } & & {$\left[\mathrm{M}+\mathrm{H}-\mathrm{C}_{2} \mathrm{H}_{5}\right]^{\bullet}$} & $\mathrm{C}_{18} \mathrm{H}_{19} \mathrm{~N}$ & 249.1523 & 249.1517 & 0.6 & 2.4 & 10.0 \\
\hline & & {$\left[\mathrm{M}+\mathrm{H}-\mathrm{CH}_{3}-\mathrm{C}_{2} \mathrm{H}_{5}\right]^{+}$} & $\mathrm{C}_{17} \mathrm{H}_{16} \mathrm{~N}$ & 234.1292 & 234.1283 & 0.9 & 3.8 & 10.5 \\
\hline & & {$\left[\mathrm{M}+\mathrm{H}-\mathrm{CH}_{3}-\mathrm{C}_{6} \mathrm{H}_{5}\right]^{+}$} & $\mathrm{C}_{13} \mathrm{H}_{16} \mathrm{~N}$ & 186.1286 & 186.1283 & 0.3 & 1.6 & 6.5 \\
\hline \multirow[t]{6}{*}{$\overline{\mathbf{P 2 9 3}}$} & 4.26 & {$[\mathrm{M}+\mathrm{H}]^{+}$} & $\mathrm{C}_{20} \mathrm{H}_{24} \mathrm{NO}$ & 294.1863 & 294.1585 & 0.5 & 1.7 & 9.5 \\
\hline & 4.44 & {$\left[\mathrm{M}+\mathrm{H}-\mathrm{C}_{2} \mathrm{H}_{5}\right]^{\bullet}$} & $\mathrm{C}_{18} \mathrm{H}_{19} \mathrm{NO}$ & 265.1478 & 265.1467 & 1.1 & 4.1 & 10.0 \\
\hline & 4.46 & {$\left[\mathrm{M}+\mathrm{H}-\mathrm{CH}_{3}-\mathrm{C}_{2} \mathrm{H}_{5}\right]^{+}$} & $\mathrm{C}_{17} \mathrm{H}_{16} \mathrm{NO}$ & 250.1244 & 250.1232 & 1.2 & 4.8 & 10.5 \\
\hline & 4.59 & {$\left[\mathrm{M}+\mathrm{H}-\mathrm{CH}_{3}-\mathrm{CH}_{3}-\mathrm{C}_{2} \mathrm{H}_{5}\right]^{\circ}$} & $\mathrm{C}_{16} \mathrm{H}_{13} \mathrm{NO}$ & 235.0992 & 235.0997 & -0.5 & -2.1 & 11.0 \\
\hline & & {$\left[\mathrm{M}+\mathrm{H}-\mathrm{CH}_{3}-\mathrm{C}_{6} \mathrm{H}_{5}\right]^{+}$} & $\mathrm{C}_{13} \mathrm{H}_{16} \mathrm{NO}$ & 202.1226 & 202.1232 & -0.6 & -3.0 & 6.5 \\
\hline & & {$\left[\mathrm{M}+\mathrm{H}-\mathrm{CH}_{3}-\mathrm{C}_{6} \mathrm{H}_{5} \mathrm{O}\right]^{+}$} & $\mathrm{C}_{13} \mathrm{H}_{16} \mathrm{~N}$ & 186.1294 & 186.1283 & 1.1 & 5.9 & 6.5 \\
\hline \multirow[t]{6}{*}{ **P309 } & 5.36 & {$[\mathrm{M}+\mathrm{H}]^{+}$} & $\mathrm{C}_{21} \mathrm{H}_{28} \mathrm{NO}$ & 310.2181 & 310.2171 & 1.0 & 3.2 & 8.5 \\
\hline & 5.49 & {$\left[\mathrm{M}+\mathrm{H}-\mathrm{C}_{2} \mathrm{H}_{7} \mathrm{~N}\right]^{+}$} & $\mathrm{C}_{19} \mathrm{H}_{21} \mathrm{O}$ & 265.1607 & 265.1592 & 1.5 & 5.7 & 9.5 \\
\hline & 5.54 & $\left.\mathrm{M}+\mathrm{H}-\mathrm{C}_{2} \mathrm{H}_{7} \mathrm{~N}-\mathrm{H}_{2} \mathrm{O}\right]^{+}$ & $C_{19} H_{19}$ & 247.1500 & 247.1487 & 1.3 & 5.3 & 10.5 \\
\hline & 5.67 & {$\left[\mathrm{M}+\mathrm{H}-\mathrm{C}_{5} \mathrm{H}_{13} \mathrm{~N}\right]^{+}$} & $\mathrm{C}_{16} \mathrm{H}_{15} \mathrm{O}$ & 223.1132 & 223.1123 & 0.9 & 4.0 & 9.5 \\
\hline & & {$\left[\mathrm{M}+\mathrm{H}-\mathrm{C}_{13} \mathrm{H}_{19} \mathrm{NO}\right]^{+}$} & $\mathrm{C}_{8} \mathrm{H}_{9}$ & 105.0699 & 105.0704 & 0.4 & 3.8 & 4.5 \\
\hline & & {$\left[\mathrm{M}+\mathrm{H}-\mathrm{C}_{14} \mathrm{H}_{21} \mathrm{NO}\right]^{+}$} & $\mathrm{C}_{7} \mathrm{H}_{7}$ & 91.0549 & 91.0548 & 0.1 & 1.1 & 4.5 \\
\hline \multirow[t]{6}{*}{$\overline{\mathbf{P 3 2 5}}$} & 4.83 & {$[\mathrm{M}+\mathrm{H}]^{+}$} & $\mathrm{C}_{21} \mathrm{H}_{28} \mathrm{NO}_{2}$ & 326.2114 & 326.2120 & -0.6 & -1.8 & 8.5 \\
\hline & 4.96 & {$\left[\mathrm{M}+\mathrm{H}-\mathrm{C}_{2} \mathrm{H}_{7} \mathrm{~N}\right]^{+}$} & $\mathrm{C}_{19} \mathrm{H}_{21} \mathrm{O}_{2}$ & 281.1550 & 281.1542 & 0.8 & 2.8 & 9.5 \\
\hline & 5.01 & {$\left[\mathrm{M}+\mathrm{H}-\mathrm{C}_{5} \mathrm{H}_{13} \mathrm{~N}\right]^{+}$} & $\mathrm{C}_{16} \mathrm{H}_{15} \mathrm{O}_{2}$ & 239.1060 & 239.1072 & -1.2 & -5.0 & 9.5 \\
\hline & 5.07 & {$\left[\mathrm{M}+\mathrm{H}-\mathrm{C}_{6} \mathrm{H}_{13} \mathrm{NO}\right]^{+}$} & $\mathrm{C}_{15} \mathrm{H}_{15} \mathrm{O}$ & 211.1115 & 211.1123 & -0.8 & -3.8 & 8.5 \\
\hline & & {$\left[\mathrm{M}+\mathrm{H}-\mathrm{C}_{14} \mathrm{H}_{23} \mathrm{~N}\right]^{+}$} & $\mathrm{C}_{7} \mathrm{H}_{5} \mathrm{O}_{2}$ & 121.0294 & 121.0290 & 0.4 & 3.3 & 5.5 \\
\hline & & {$\left[\mathrm{M}+\mathrm{H}-\mathrm{C}_{14} \mathrm{H}_{23} \mathrm{NO}\right]^{+}$} & $\mathrm{C}_{7} \mathrm{H}_{5} \mathrm{O}$ & 105.0340 & 105.0340 & 0.0 & 0.0 & 5.5 \\
\hline \multirow[t]{5}{*}{$\overline{\mathbf{P 3 4 1}}$} & 3.70 & {$[\mathrm{M}+\mathrm{H}]^{+}$} & $\mathrm{C}_{21} \mathrm{H}_{28} \mathrm{NO}_{3}$ & 342.2055 & 342.2069 & -1.4 & -4.1 & 8.5 \\
\hline & 3.94 & {$\left[\mathrm{M}+\mathrm{H}-\mathrm{C}_{2} \mathrm{H}_{7} \mathrm{~N}\right]^{+}$} & $\mathrm{C}_{19} \mathrm{H}_{21} \mathrm{O}_{3}$ & 297.1490 & 297.1491 & -0.1 & -0.3 & 9.5 \\
\hline & 4.15 & {$\left[\mathrm{M}+\mathrm{H}-\mathrm{C}_{5} \mathrm{H}_{13} \mathrm{~N}\right]^{+}$} & $\mathrm{C}_{16} \mathrm{H}_{15} \mathrm{O}_{3}$ & 255.1030 & 255.1021 & 0.9 & 3.5 & 9.5 \\
\hline & & {$\left[\mathrm{M}+\mathrm{H}-\mathrm{C}_{6} \mathrm{H}_{13} \mathrm{NO}\right]^{+}$} & $\mathrm{C}_{15} \mathrm{H}_{15} \mathrm{O}_{2}$ & 227.1069 & 227.1072 & -0.3 & -1.3 & 8.5 \\
\hline & & {$\left[\mathrm{M}+\mathrm{H}-\mathrm{C}_{14} \mathrm{H}_{23} \mathrm{NO}\right]^{+}$} & $\mathrm{C}_{7} \mathrm{H}_{5} \mathrm{O}_{2}$ & 121.0290 & 121.0290 & 0.0 & 0.0 & 5.5 \\
\hline
\end{tabular}

${ }^{a}$ If no symbol is written, the phototransformation product was identified in samples collected during photolysis and the two investigated photocatalytic treatments

* Only generated during the two investigated photocatalytic treatments

** Only generated during photolysis of MET 


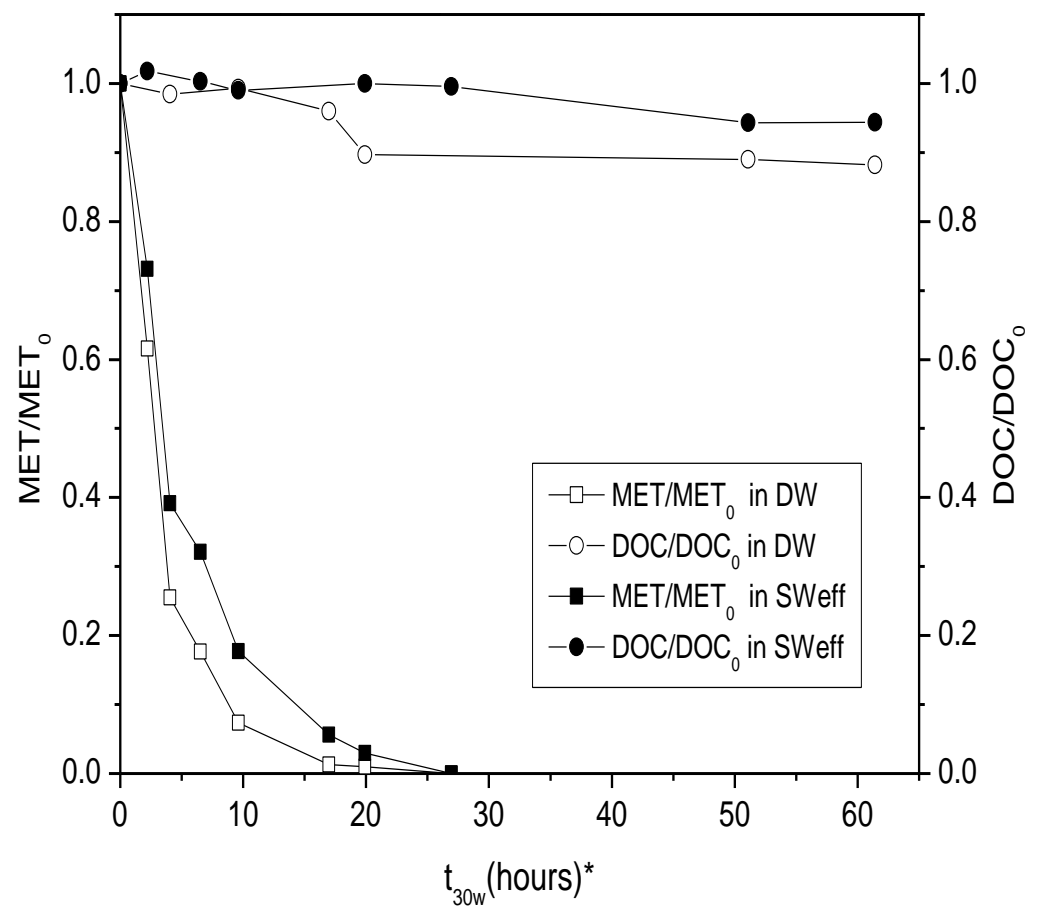

Figure 1 
$-\square-M E T / M E T_{0}$ in DW $-0-D_{0} O C / D O C_{0}$ in DW

- - MET/MET $T_{0}$ in SW eff $-\bullet-D^{\prime} O C / D O C_{0}$ in $S_{\text {eff }}$
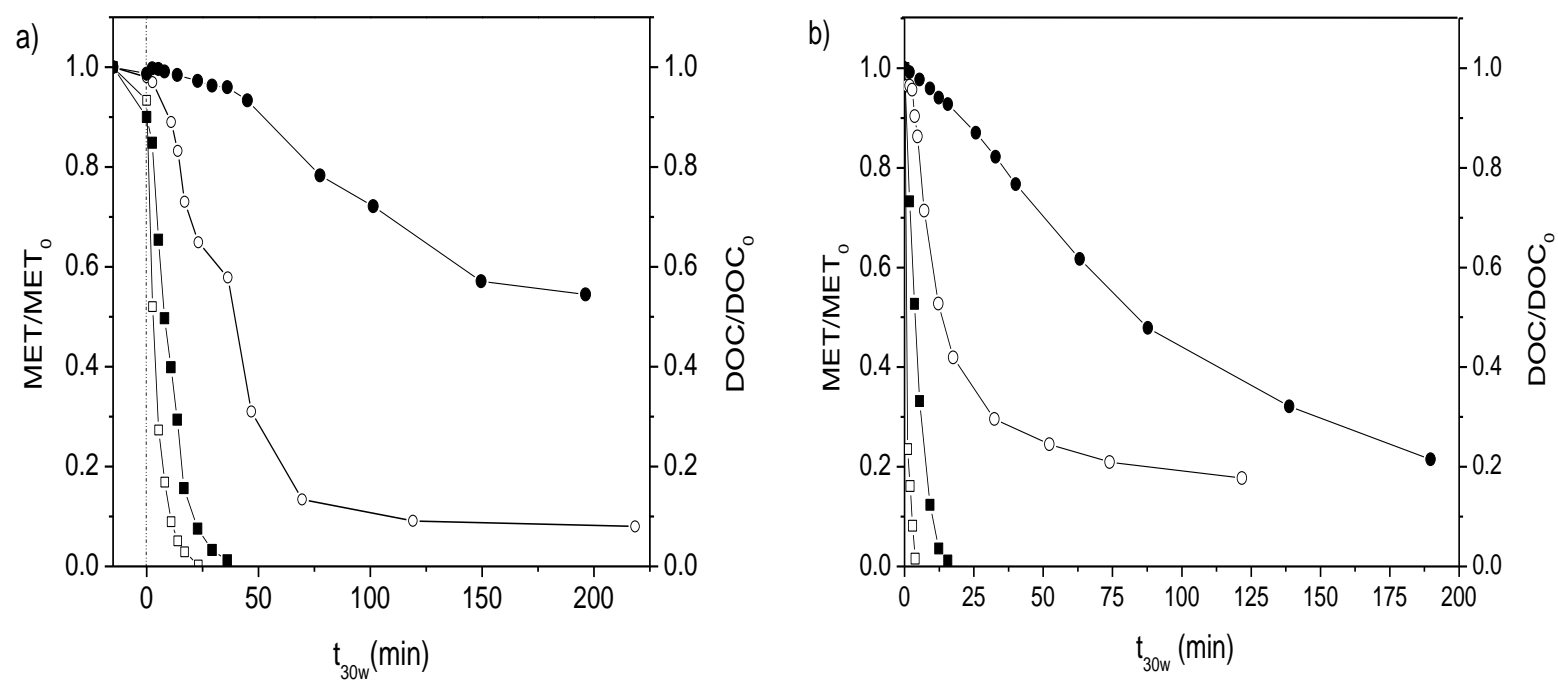

Figure 2 

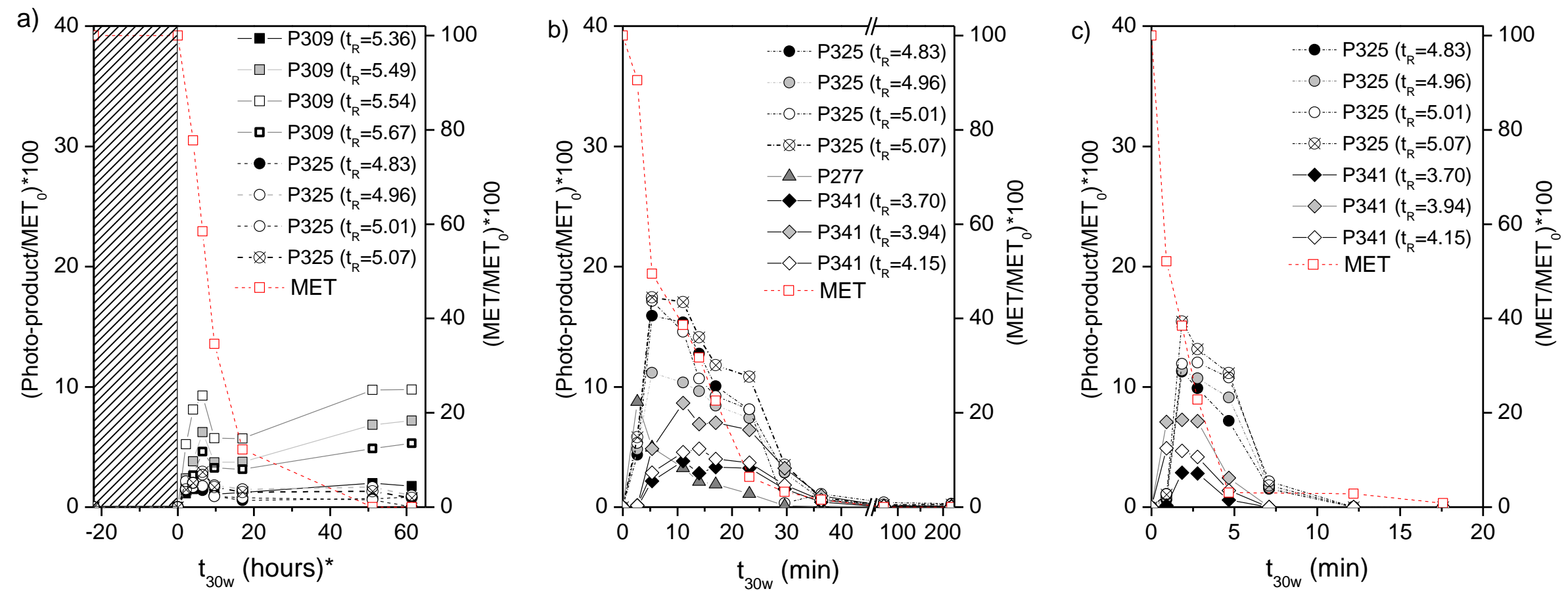

Figure 3. 


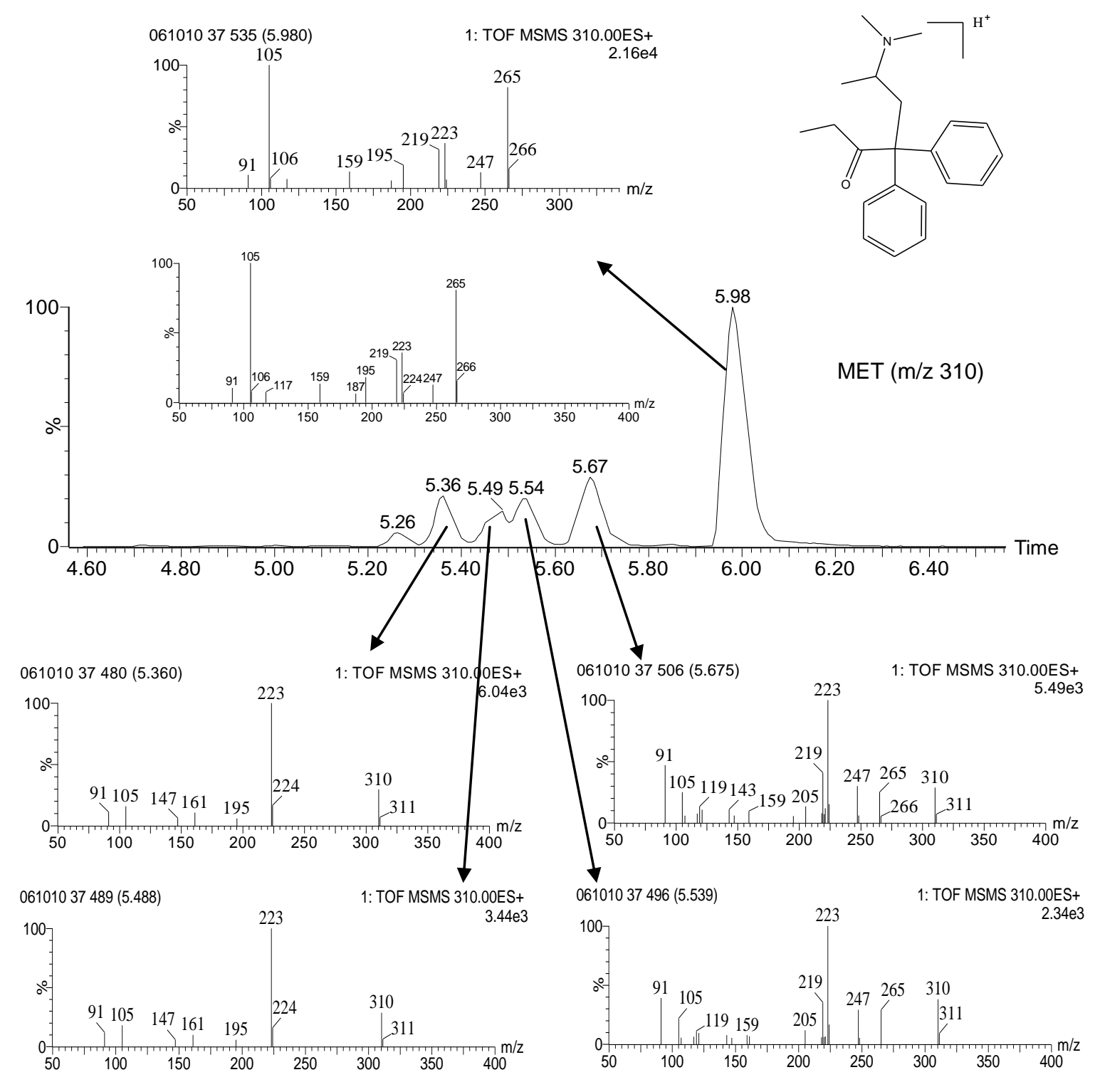

Figure 4. 


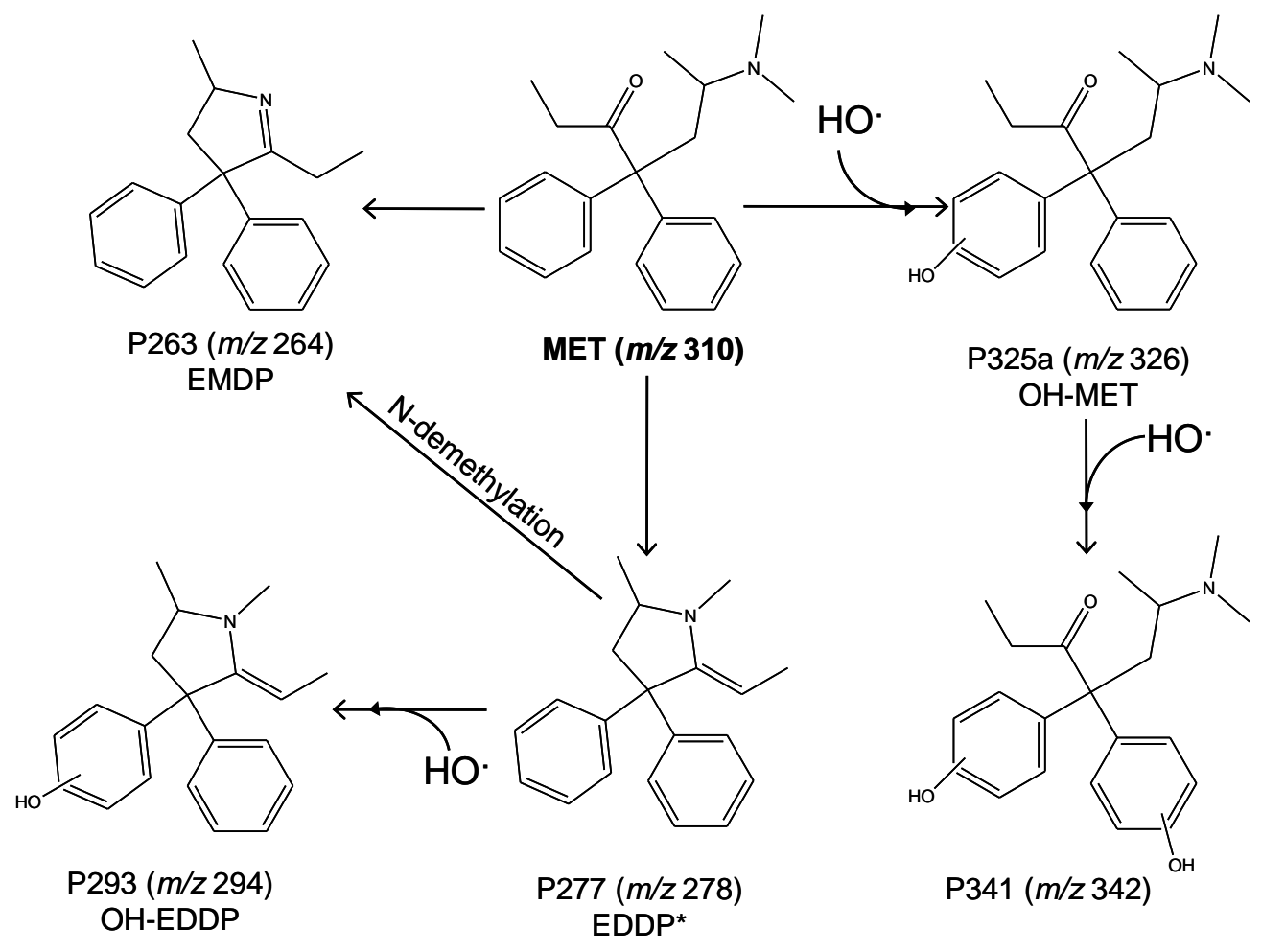

Figure 5. 

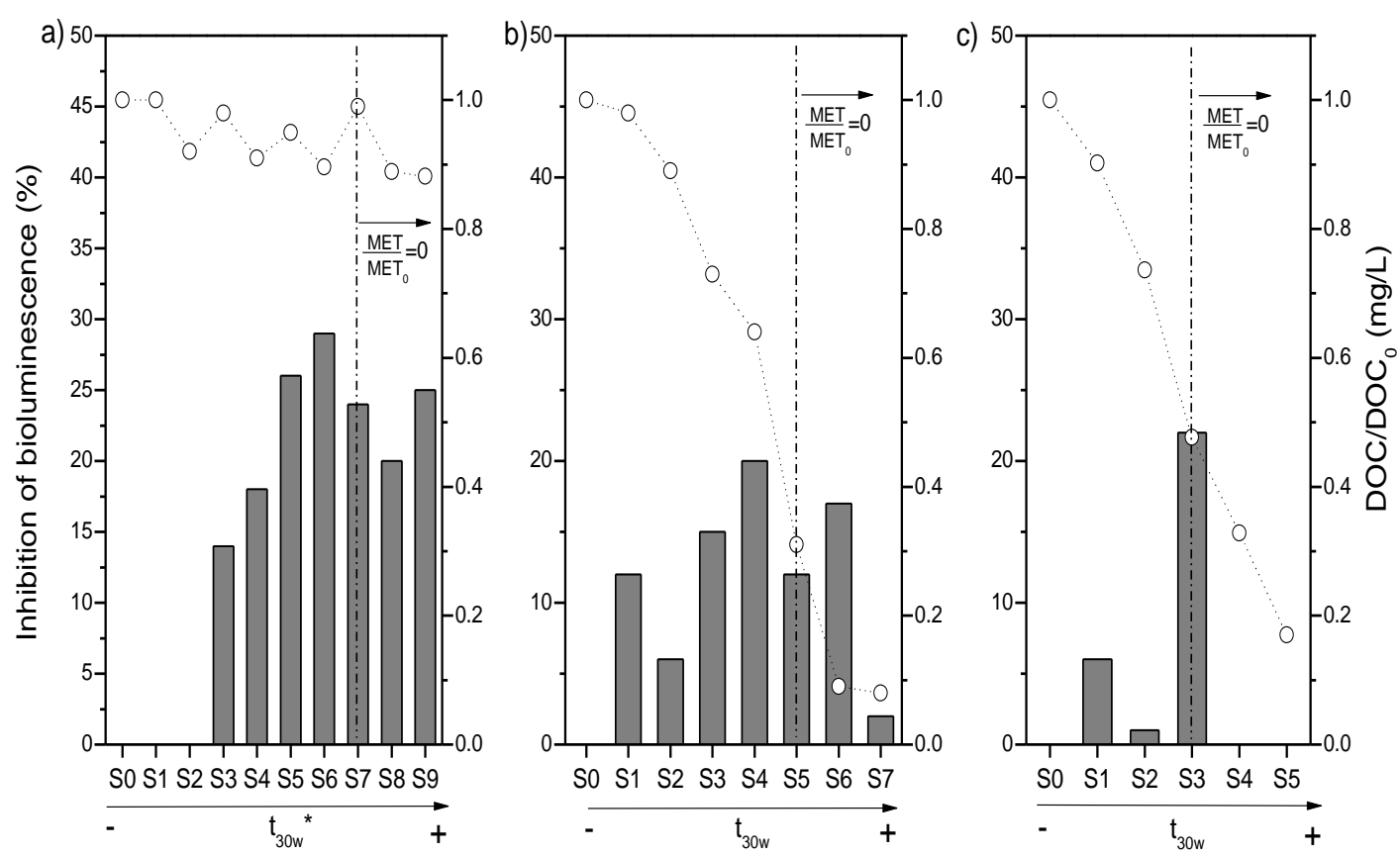

Figure 6 . 


\section{Supplementary material}

Table S1. Chemical composition of the synthetic sewage water effluent (SWeff) (DOC $\approx 30$ $\mathrm{mg} / \mathrm{L})$.

\begin{tabular}{|l|c|l|}
\hline & $\begin{array}{c}\text { Concentration } \\
(\mathrm{mg} / \mathrm{L})\end{array}$ & \multicolumn{1}{|c|}{ Provider } \\
\hline Peptone & 32 & Biolife Italiana, Italy \\
\hline Meat extract & 22 & Biolife Italiana, Italy \\
\hline Urea & 6 & Fluka, Switzerland \\
\hline $\mathrm{Mg}_{2} \mathrm{SO}_{4} \cdot 7 \mathrm{H}_{2} \mathrm{O}$ & 2 & Fluka, Switzerland \\
\hline $\mathrm{NaCl}$ & 7 & Merck, Germany \\
\hline $\mathrm{K}_{2} \mathrm{HPO}_{4}$ & 28 & Merck, Germany \\
\hline $\mathrm{CaCl}_{2} \cdot \mathrm{H}_{2} \mathrm{O}$ & 4 & Riedel-de Haën, Germany \\
\hline $\mathrm{NaHCO}_{3}$ & 96 & Riedel-de Haën, Germany \\
\hline $\mathrm{CaSO}_{4} \cdot 2 \mathrm{H}_{2} \mathrm{O}$ & 60 & Panreac, Spain \\
\hline $\mathrm{MgSO}_{4}$ & 60 & Sigma-Aldrich, Spain \\
\hline $\mathrm{KCl}$ & 4 & J.T.Baker, Netherlands \\
\hline
\end{tabular}


a) 1

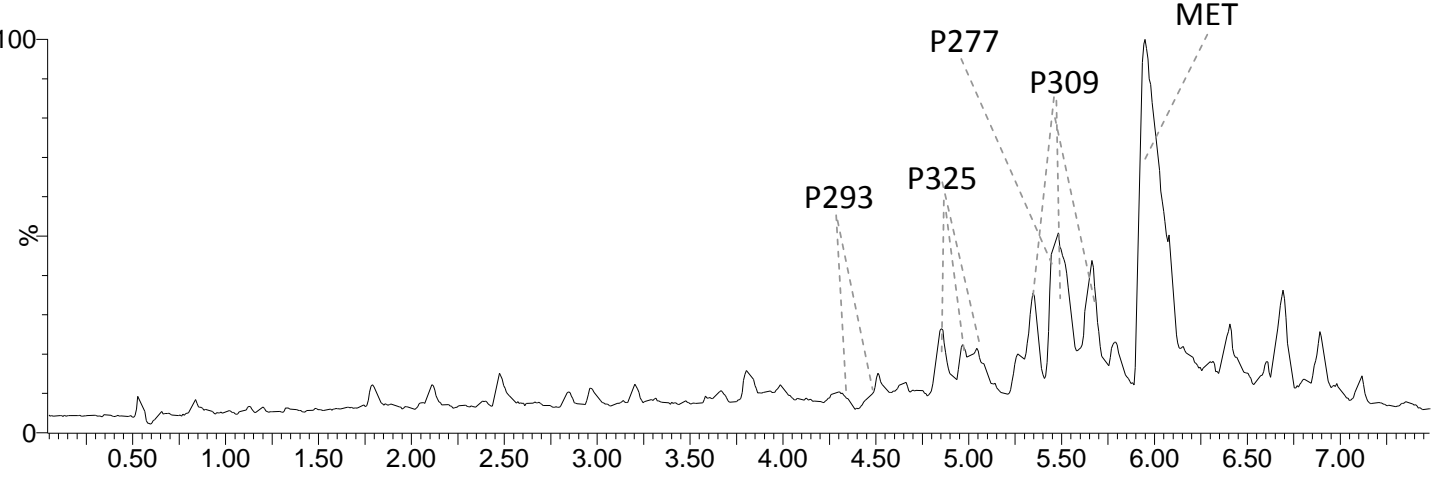

b) 100

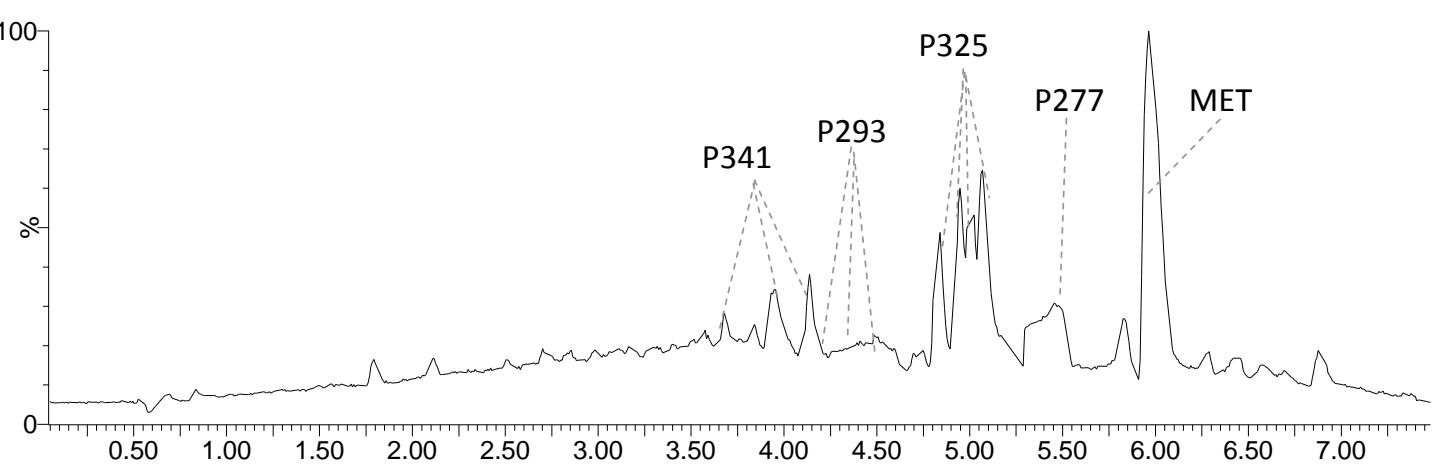

c) 100

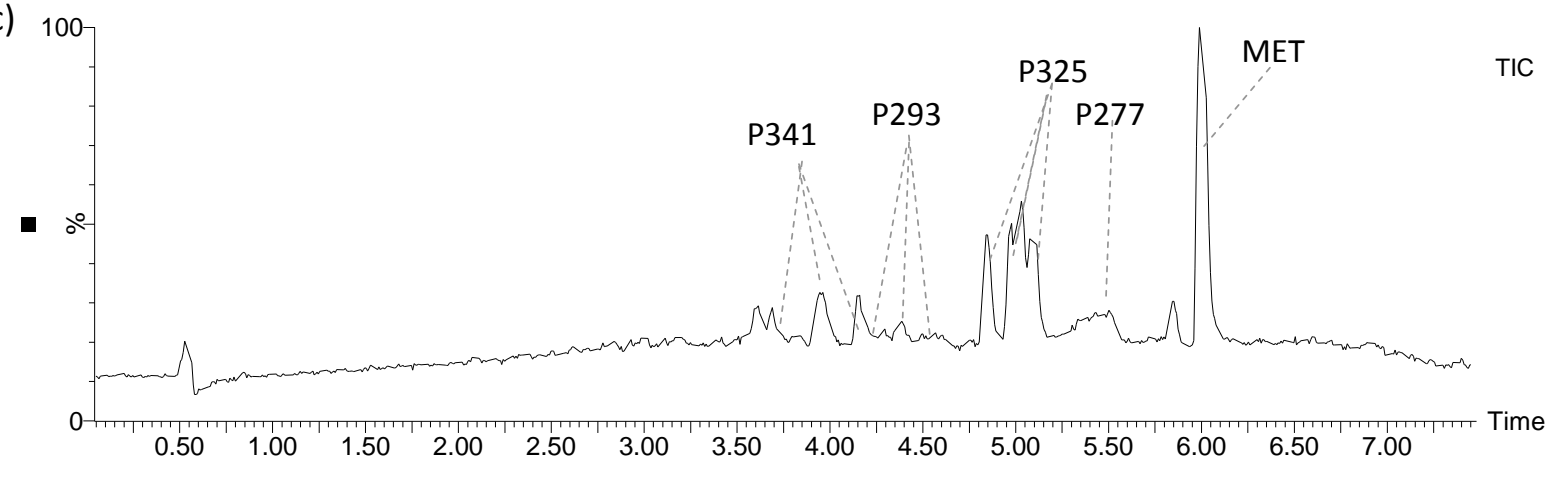

Figure S1. Total ion current (TIC) chromatograms obtained after UPLC-QqToF-MS full-scan analysis of representative preconcentrated DW samples collected during a) photolysis, b) solar heterogeneous photocatalysis with $\mathrm{TiO}_{2}$, and c) solar photo-Fenton experiments of MET. The most abundant phototransformation intermediates are identified on the chromatograms. 


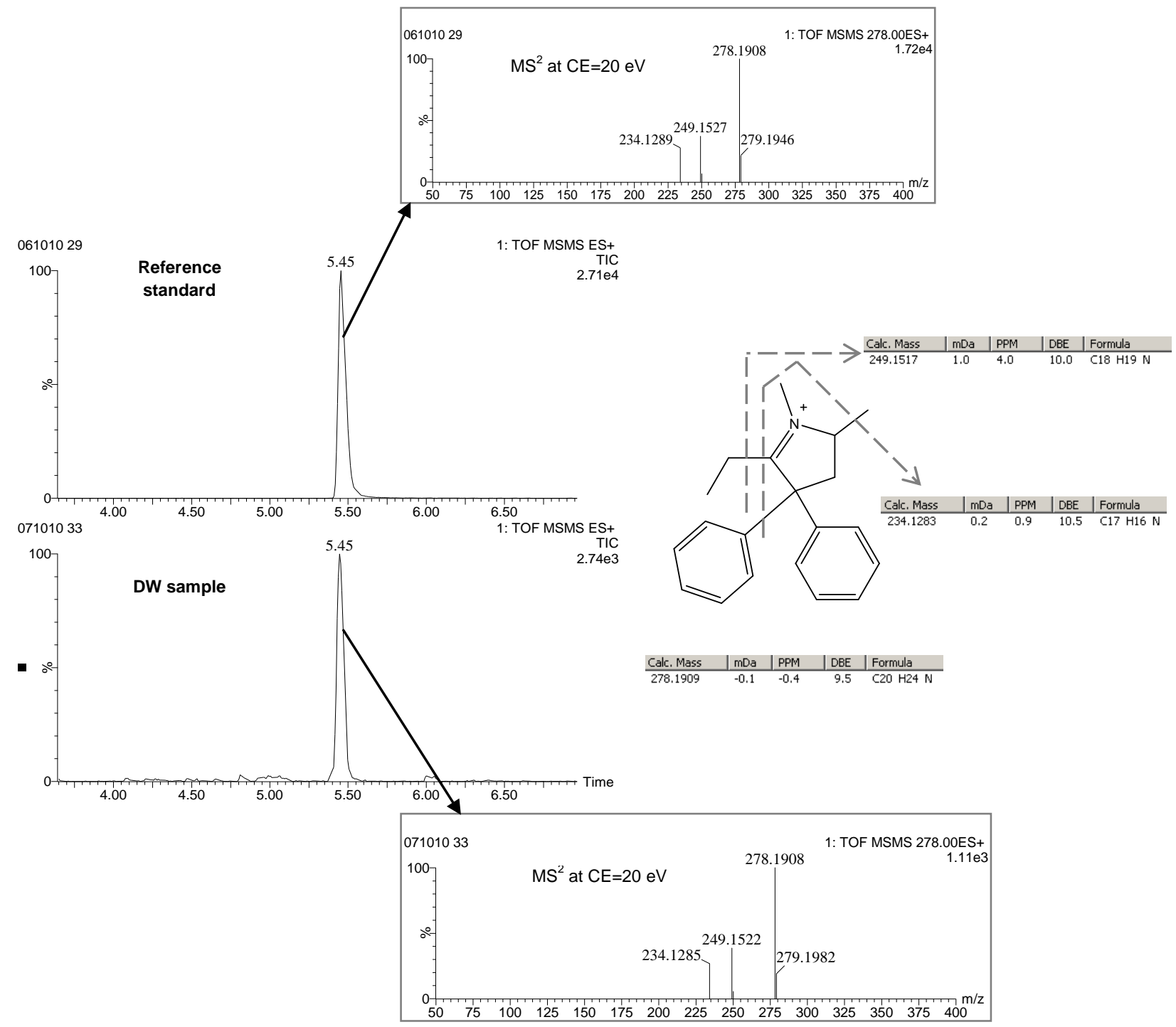

Figure S2. Chromatogram and spectra obtained with MS/MS experiments of P277 (CE=20 eV) in a reference standard solution of EDDP and in a DW sample collected during the $\mathrm{TiO}_{2}$ heterogeneous photocatalysis treatment. 

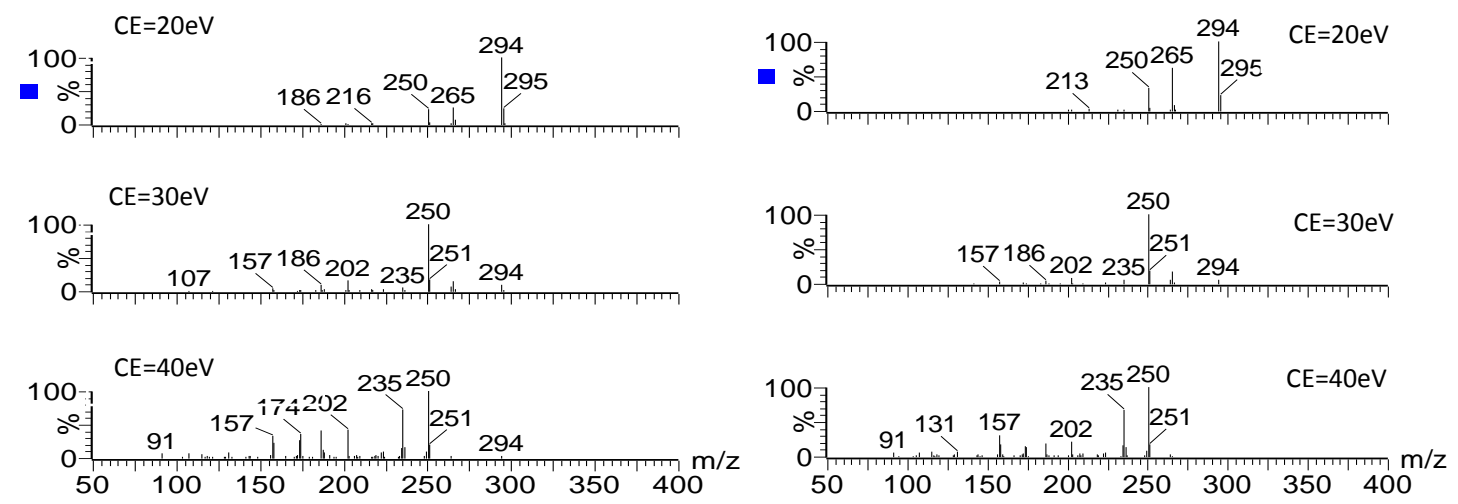

2

3

4

5
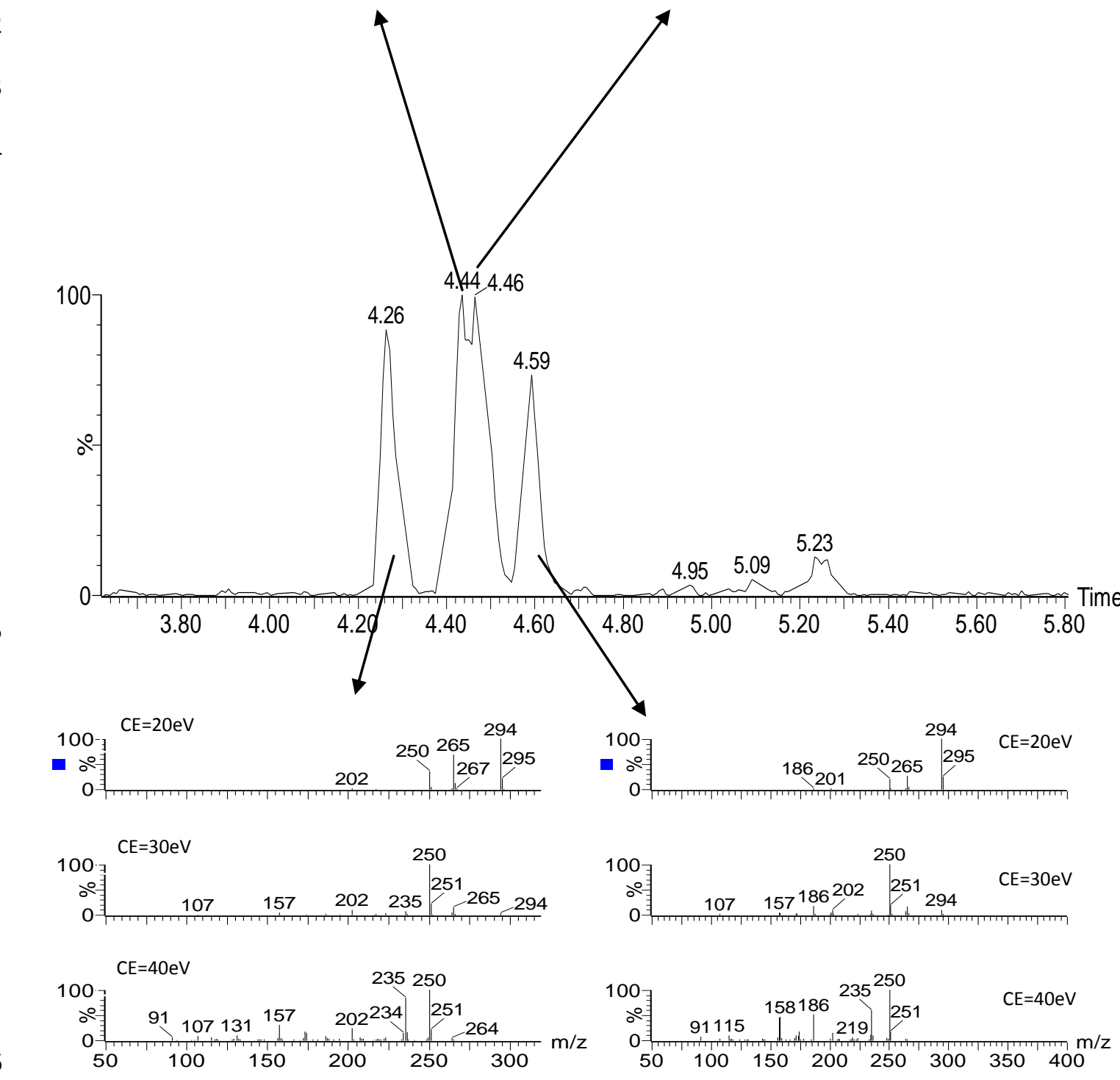

7 Figure S3. Chromatogram and spectra obtained with MS/MS experiments of P293 at different collision energies (CE) in a DW sample collected during the $\mathrm{TiO}_{2}$ heterogeneous photocatalysis treatment. 


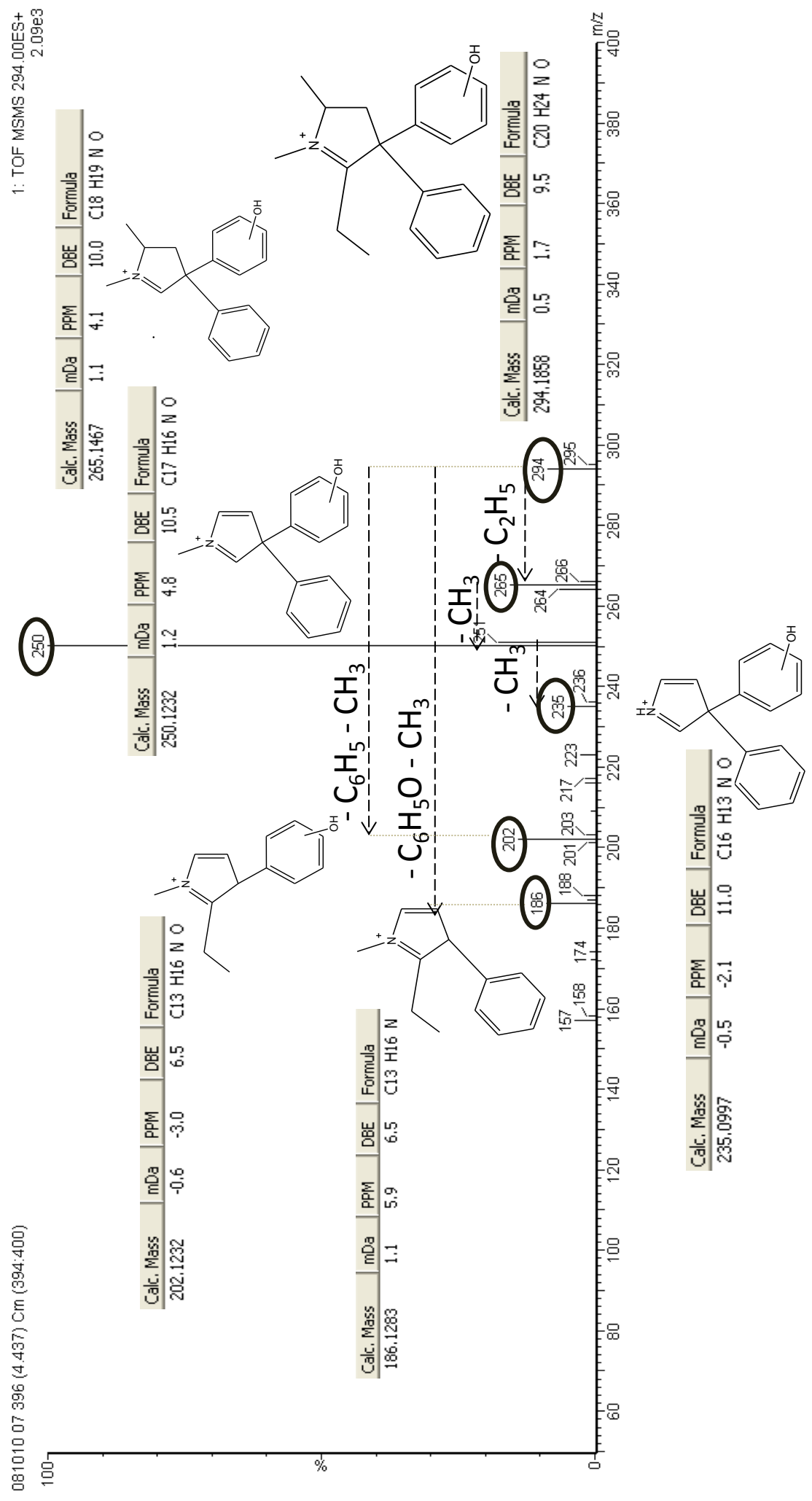

Figure S4. Main fragment ions proposed for the photo-transformation products P293. 


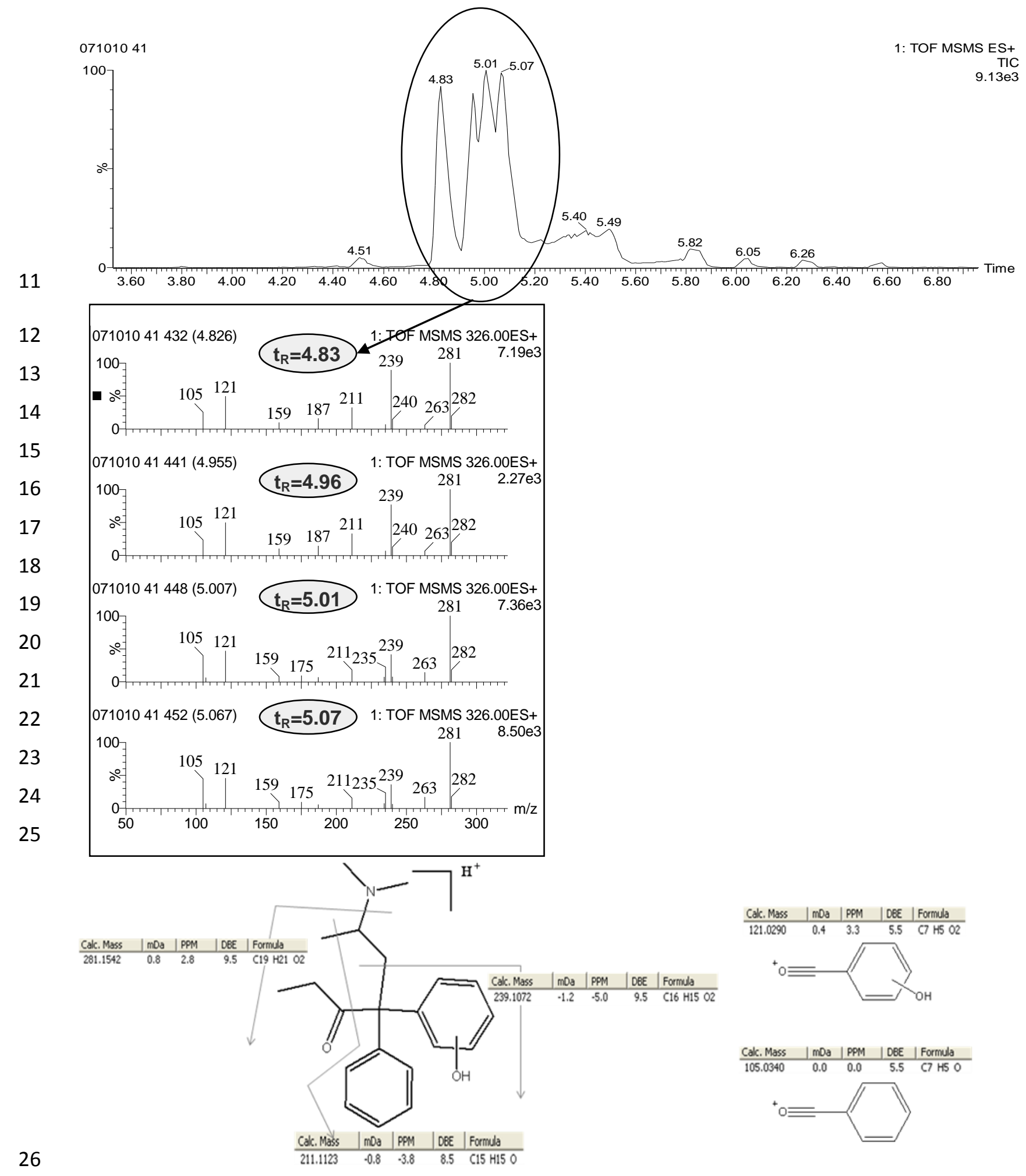

27 Figure S5. Chromatogram and fragmentation spectra of the monohydroxylated derivatives of MET (P325) obtained with the $\mathrm{MS}^{2}$ analysis of a DW sample collected during photo-Fenton at a collision energy of $20 \mathrm{eV}$. Main fragmentation routes proposed are also shown. 


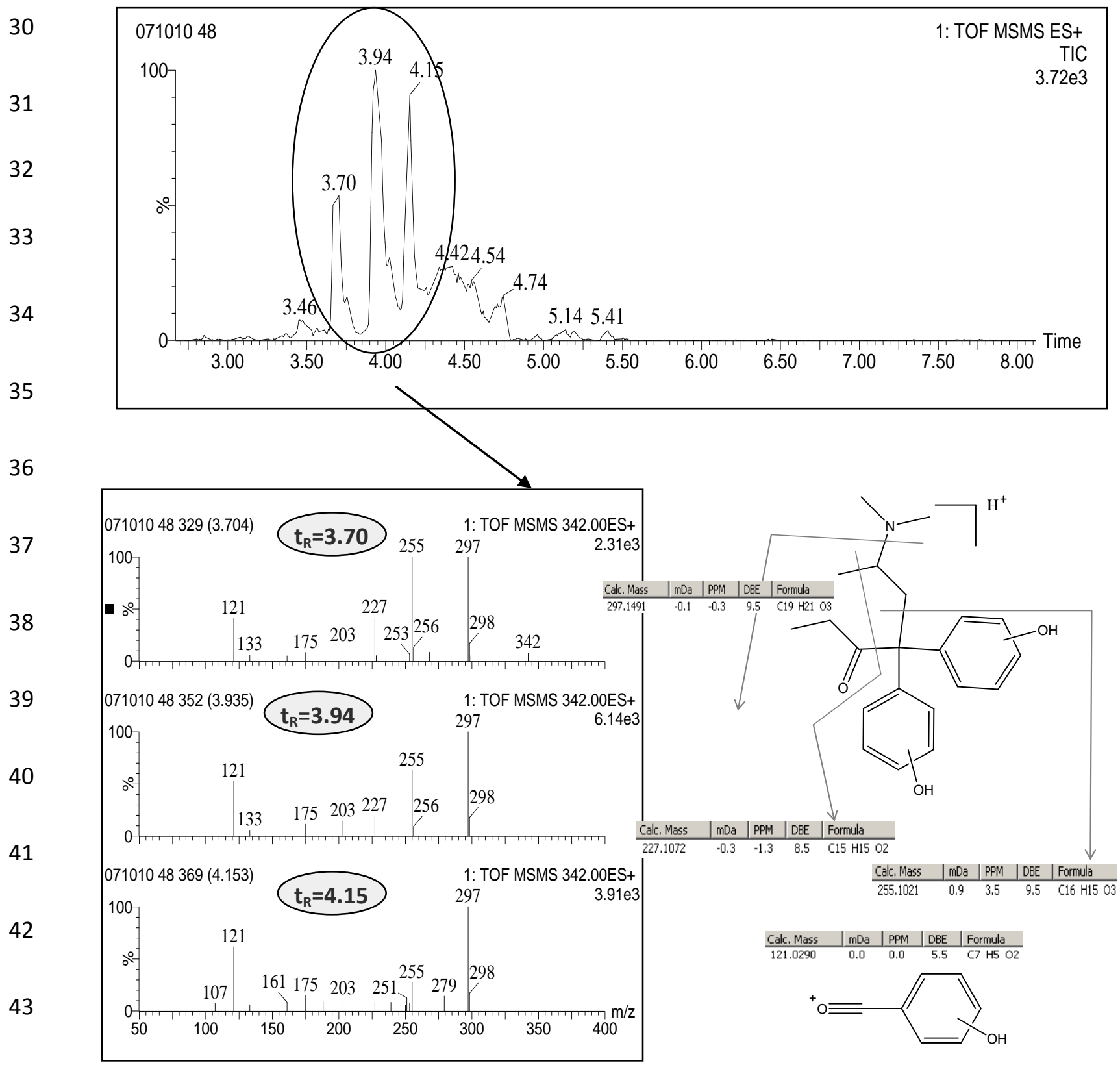

44

45 Figure S6. Chromatogram and spectra of the dihydroxilated derivatives of MET obtained with MS/MS

46 analysis of a DW sample collected during the heterogeneous photocatalysis with $\mathrm{TiO}_{2}$ at a collision

47 energy of $20 \mathrm{eV}$. Main fragmentation routes proposed are also shown. 